\title{
Observing intermittent biological productivity and vertical carbon transports during the spring transition with BGC Argo floats in the western North Pacific
}

Chiho Sukigara ${ }^{1}$, Ryuichiro Inoue ${ }^{2}$, Kanako Sato ${ }^{2}$, Yoshihisa Mino $^{3}$, Takeyoshi Nagai ${ }^{1}$, Andrea J.

Fassbender ${ }^{4,5}$, Yuichiro Takeshita ${ }^{5}$, Stuart Bishop ${ }^{6}$, and Eitarou $\mathrm{Oka}^{7}$

5

${ }^{1}$ Tokyo University of Marine Science and Technology, Tokyo, 1088477, Japan

2 Japan Agency for Marine-Earth Science and Technology, Yokosuka, 2370061, Japan

${ }^{3}$ Institute for Space-Earth Environmental Research, Nagoya University, Nagoya, 4648601, Japan

${ }^{4}$ NOAA/OAR Pacific Marine Environmental Laboratory, Washington, 98115, USA

$10 \quad{ }^{5}$ Monterey Bay Aquarium Research Institute, California, 95039, USA

${ }^{6}$ North Carolina State University, Raleigh, North Carolina, 27695, USA

${ }^{7}$ Atmosphere and Ocean Research Institute, The University of Tokyo, Kashiwa, 2778564, Japan

Correspondence: Chiho Sukigara (csukig0@kaiyodai.ac.jp)

15 Key words: BGC Argo float, mixing-restratification process, biological productivity, particulate organic matter, vertical carbon transport

Abstract. To investigate changes in ocean structure during the spring transition and responses of biological activity, two BGC-Argo floats equipped with oxygen, fluorescence (to estimate chlorophyll $a$ concentration - Chl $a$ ), backscatter (to estimate particulate organic carbon concentration - [POC]), and nitrate sensors conducted daily vertical profiles of the water column from a depth of $2000 \mathrm{~m}$ to the sea surface in the western North Pacific from January to April of 2018. Data for calibrating each sensor were obtained via shipboard sampling that occurred when the floats were deployed and recovered. During the float-deployment periods, repeated meteorological disturbances passed over the study area and caused the mixed layer to deepen. After deep-mixing events, the upper layer restratified and nitrate concentrations decreased while $\mathrm{Chl} a$ and POC concentrations increased, suggesting that spring mixing 
events promote primary productivity through the temporary alleviation of nutrient and light limitation. At the end of March, POC accumulation rates and nitrate decrease rates within the euphotic zone $(0-70 \mathrm{~m})$ were the largest of the four events observed, ranging from +84 to $+210 \mathrm{mmol} \mathrm{C} \mathrm{m}^{-2} \mathrm{~d}^{-1}$ and -28 to -49 mmol $\mathrm{N} \mathrm{m}^{-2} \mathrm{~d}^{-1}$, respectively. The subsurface consumption rate of oxygen (i.e., the degradation rate of organic matter) after the fourth event (the end of March) was estimated to be $-0.62 \mu \mathrm{mol} \mathrm{O}_{2} \mathrm{~kg}^{-1} \mathrm{~d}^{-1}$. At depths of 300-400 m (below the mixed layer), the POC concentrations increased slightly throughout the observation period. The POC flux at a depth of $300 \mathrm{~m}$ was estimated to be $1.1 \mathrm{mmol} \mathrm{C} \mathrm{m} \mathrm{d}^{-1}$. Our float observation has made it possible to observed biogeochemical parameters, which previously could only be estimated by shipboard observation and experiments, in the field and in real time.

\section{Introduction}

Particulate matter in the ocean plays an important role in the global carbon cycle. Sinking organic particles transport carbon from the surface to the ocean interior, sequester carbon in the deep ocean, and act to lower the atmospheric $\mathrm{CO}_{2}$ concentration (Sarmiento and Gruber, 2006; Giering et al., 2020). A series of events associated with organic particle production in the euphotic zone, sinking through the water column, and remineralization beneath the surface layer is referred to as the "biological pump" (Volk and Hoffert, 1985; Giering and Humphreys, 2018). The vertical transport of particulate organic carbon (POC) has been ascribed mainly to the gravitational sinking of particles, with other particle transport processes playing supporting roles (Sanders et al., 2014; Seigel et al., 2014; Boyd et al., 2019; Resplandy et al., 2019). Thus, a key control on the magnitude and efficiency of the biological pump is the sinking velocity of particles.

Particle sinking velocities span over an order of magnitude, from ten to a few hundred meters per day (Turner 2002; Armstrong et al., 2009), and may be determined by the size, shape, and chemical composition of the particles (Wilson et al., 2008; Ploug et al., 2008; Iversen and Ploug, 2010; Sukigara et al., 2019). Rapidly sinking particles (i.e., $>20 \mathrm{~m} \mathrm{~d}^{-1}$ ) can efficiently transport POC to the ocean interior with little remineralization over a short period of time (Billett et al., 1983). Conversely, slowly sinking and suspended particles are likely remineralized at shallow depths, where they return $\mathrm{CO}_{2}$ to the water column and thus limit the efficiency of the biological pump (Buesseler et al., 2007). It is important to 
investigate the distribution and dynamics of slowly sinking and suspended particles as well as rapidly sinking particles to clarify their contributions to the marine carbon cycle (Alldredge and Silver, 1988; Kwon et al., 2009, Alonso-González et al.,2010).

There are presently not enough observations of particles in the ocean to comprehensively assess their distributions and behaviors. One key reason for this paucity of observations is the difficulty associated with observing the behavior of sinking or suspended particles in the water column. Discrete observations require that several liters of water be collected and filtered from multiple depths to determine the amount and distribution of POC in the water column. Furthermore, the temporal and spatial resolutions of the data have been low because of the challenges associated with ship-borne observations during stormy weather. However, it has become possible to estimate the amount of POC from observations by optical sensors (e.g., backscatter) in the last decade (Briggs et al., 2011; Cetinić et al., 2012; Dall'Omlo et al., 2014; Briggs et al., 2020). The growing use of these sensors on Argo floats will make it possible to acquire observations during all seasons and study particle transport in more detail.

In recent years, carbon export to the ocean interior through the process of seasonal mixed layer deepening has been observed with Argo floats and is now commonly referred to as the "mixed-layer pump" (MLP; Dall'Olmo et al., 2016; Lacour et al., 2019). Seasonal mixed layer deepening from winter to early spring is caused by wind mixing and heat loss to the atmosphere (Price et al., 1986). This deep mixing can quickly transport suspended and slowly sinking particles as well as dissolved matter below the seasonal pycnocline and euphotic zone (Gardner et al., 1995). During deep winter mixing events in the high latitudes, carbon exported via the MLP is equivalent to $\sim 23 \%$ of the carbon exported gravitationally by rapidly sinking particles, on average (Dall'Olmo et al., 2016). Nevertheless, few studies have addressed how the MLP influences the global carbon cycle and recent work has clarified that persistent, rapid profiling may be required to quantify particle export occurring via this mechanism (Xing et al., 2020).

In this study, both shipboard and biogeochemical (BGC) Argo floats were used to make winter to spring observations of physical and biogeochemical processes in the subtropical region south of the Kuroshio Extension in the western North Pacific Ocean. This region contributes to the formation of 
subtropical mode water (STMW) and is known to develop a deep mixed layer (300-400 m) during late winter (Hanawa and Tally, 2001; Qiu et al., 2006, 2007). Moreover, formation of a deep mixed layer entrains nutrients from below the base of the seasonal pycnocline that support active primary production in the early spring as the mixed layer sporadically shoals and deepens, allowing for episodic particle subduction by the MLP. Although persistent seasonal shoaling of the mixed layer is caused by solar radiation warming the ocean surface, Mahadevan et al. (2012) have shown that rapid restratification events in ocean frontal regions can also occur during the formation of mixed layer eddies. As a result, it is important to simultaneously analyse the physical and biogeochemical ocean conditions during the spring transition to achieve proper attribution of the processes driving carbon export.

Our field study aimed to observe the temporal transition in biological production from a well-mixed winter water column to a warm, stratified spring water column that experiences high-light and nutrientreplete conditions. This period of the year is associated with the highest annual primary productivity rates (Matsumoto et al., 2016) as well as elevated particle fluxes from the euphotic layer to depth (Honda et al., 2016). Using chemical and biological measurements from daily-profiling BGC Argo floats, we isolated times when local physical processes were largely one dimensional to study changes in biological and chemical parameters that occurred during rapid transitions from deep mixing to intermittent stratification. We quantified the production of POC in the euphotic zone and its fate in the mesopelagic to evaluate how these short periods of productivity between episodes of deep mixing contributed to vertical carbon exchanges during the spring transition.

\section{Materials and methods}

\subsection{Float measurements}

On 28 January 2018, during cruise KS-18-1 of the R/V Shinsei Maru (18-30 January 2018), two Navis BGC Autonomous Profiling floats (Sea-Birds Scientific, USA: World Meteorological Organization nos. 2903329 and 2903330 ) were launched at $33.25^{\circ} \mathrm{N}, 142.50^{\circ} \mathrm{E}$ in the Kuroshio recirculation gyre, south of the Kuroshio Extension (Fig. 1). The floats moved in a small clockwise trajectory around $33^{\circ} \mathrm{N}, 142^{\circ} \mathrm{E}$ for approximately one month and then moved southwest for two weeks, maintaining a separation $<20 \mathrm{~km}$, 
until mid-March. Around $13 \mathrm{March}$, the floats turned north from their southernmost location of $32.42^{\circ} \mathrm{N}$ and float 2903330 remained west of float 2903329 until recovery. In late March, they slowed for approximately one week and thereafter maintained a separation of about $25 \mathrm{~km}$. After 6 April, the direction of the floats changed to the northeast, and their speed increased. Several observations just before recovery indicated that the floats may have been influenced by the Kuroshio Extension. The floats were recovered during cruise KS-18-4 of the R/V Shinsei Maru (20 April to 1 May 2018).

Each float was programmed to profile daily, reaching the sea surface at 12:00-14:00 UTC (21:0023:00 local time), and remained there for about $15 \mathrm{~min}$ to transmit data via the Iridium satellite-based wireless communication system before returning to its parking depth. Each float was equipped with an SBE41CP conductivity-temperature-depth (CTD) sensor (Sea-Bird Electronics, Inc., Bellevue, USA). After descending from a parking depth of $1000 \mathrm{dbar}$ to a depth of $2000 \mathrm{dbar}$, the floats measured CTD data (vertical sampling interval of 2 dbar) during their subsequent ascent to the sea surface. The floats were also equipped with an optical dissolved oxygen (DO) sensor (SBE63); a nitrate sensor (DeepSUNA); and a sensor that measured chlorophyll (Chl) fluorescence, 700-nm optical backscatter, and fluorescent dissolved organic matter (fDOM; MCOMS, WETLabs, USA).

\subsection{Shipboard observations}

Discrete data presented here were collected during two cruises (KS-18-1, 18-30 January 2018, and KS18-4, 20 April to 1 May 2018) of R/V Shinsei-maru. Ship-based sampling was performed using a rosette equipped with twenty-four 12-L Niskin bottles, a 9PLUS CTD sensor, and an SBE43 oxygen sensor (SeaBird Scientific, USA). We collected CTD observations from $2000 \mathrm{~m}$ to the sea surface at the deployment location $\left(33.25^{\circ} \mathrm{N}, 142.5^{\circ} \mathrm{E}\right.$; station $\mathrm{C} 005$ during cruise KS-18-1) of both BGC-Argo floats and at the recovery location $\left(35.52^{\circ} \mathrm{N}, 143.18^{\circ} \mathrm{E}\right.$; station $\mathrm{C} 002$ during cruise $\left.\mathrm{KS}-18-4\right)$ of one of the floats (WMO 2903329) (Fig. 1). Water samples for salinity, nutrient concentrations, DO concentration, chlorophyll $a$ (Chl $a$ ), and POC were collected to calibrate sensors on the CTD and floats. During cruise KS-18-1, the CTD was equipped with a photosynthetically active radiation (PAR) sensor (LI-COR Biospherical PAR 
sensor, Biospherical Instruments Inc., USA) to measure light in the water column. The bottom of the euphotic zone $(70 \mathrm{~m})$ was defined as the depth at which the PAR was $1 \%$ of the surface value.

\subsection{Calibration of float sensors}

\subsubsection{DO and nitrate}

The DO concentrations in sampled water were measured with an onboard titration unit (MPT Titrino 798: Metrohm, Japan) and used to calibrate an SBE43 oxygen sensor. The water samples for measurements of nitrate concentrations were immediately frozen at $-20{ }^{\circ} \mathrm{C}$ and kept in a freezer until the nutrient concentrations were measured with an autoanalyzer (QuAAtro: BL Tec, Japan). The nitrate was reduced to nitrite using a cadmium-copper column, and the nitrite concentration was determined based on the absorption of an azo dye at a wavelength of $550 \mathrm{~nm}$ (Grasshoff, 1976).

In the case of DO, the sensor output values from floats were first converted to oxygen concentrations following standard protocols outlined in Thierry et al. (2018) and using adjusted salinity data based on Wong et al. (2020). Oxygen concentrations from each float's first profile were compared with CTD observations made at the time of the float deployments. A linear regression between float and CTD values from a region of the water column in which the oxygen gradient was less than $0.2 \mu \mathrm{mol} \mathrm{O} \mathrm{Og}^{-1} \mathrm{dbar}^{-1}$ was used to determine the gain of the float sensor (Takeshita et al., 2013). We used the difference in oxygen concentration between the last float profile and the CTD profile at the time of float recovery to determine the drift correction for each $0.01 \mathrm{~kg} \mathrm{~m}^{-3}$ of potential density $\left(\sigma_{\theta}\right)$ larger than $27.5 \sigma_{\theta}$. The gaincorrected float oxygen data were then adjusted at each time step by applying the average drift rate to the entire profile over time.

For nitrate, the sensor output values were converted to nitrate concentrations following standard protocols outlined in Johnson et al. (2016). The optical wavelength offset, which accounts for the uncertainty in the wavelength registration of the diode array spectrometer, was adjusted to minimize the difference between the discrete and sensor nitrate concentration from the deployment cast. Corrected nitrate concentrations were calculated using the new optical wavelength offset. Subsequent data quality 

(Maurer et al., 2021 following Johnson et al., 2017).

\subsubsection{Chl $a$}

Water samples for Chl $a$ analysis were collected from the float deployment and recovery stations. The vertical resolution of Chl $a$ sampling was $25 \mathrm{~m}$ in the top $200 \mathrm{~m}$ and $50 \mathrm{~m}$ at depths of $200-400 \mathrm{~m}$. Seawater $(200 \mathrm{~mL})$ was poured from a Niskin bottle into a light-shielding bottle. Water samples were filtered through Grade GF/F Whatman 25-mm glass fiber filters (Cytiva Life Sciences, USA). The Chl $a$ on the filter was extracted immediately after filtration in $7 \mathrm{~mL}$ of dimethylformamide in a freezer at $-20{ }^{\circ} \mathrm{C}$. The extracted $\mathrm{Chl} a$ was measured onboard using a fluorometer (10-AU, Turner Designs, USA).

A linear relationship was found between extracted Chl $a$ concentrations and float fluorescence values, excluding observations from the top $100 \mathrm{~m}$ at the recovery station (Fig. 2). For this comparison, fluorescence values were averaged within $\pm 5 \mathrm{~m}$ of each $\mathrm{Chl} a$ sampling depth. The difference between the Chl $a$ concentrations and fluorescence values in the surface water was likely due to the sampling of different water masses, as the surface layer densities from the CTD and float differed by $0.1 \mathrm{~kg} \mathrm{~m}^{-3}$, thus was not used to correct the float fluorometer.

We used the empirical relationship between Chl $a$ concentration and fluorescence based on data from both cruises to estimate the $\mathrm{Chl} a$ concentration for each daily float profile:

Chl $a\left(\mathrm{mg} \mathrm{m}^{-3}\right)=$ fluorescence value $\times 0.952+0.014, \quad r^{2}=0.88$

\subsubsection{POC}

Water samples for POC were also collected at the float deployment and recovery stations. Seawater (5-7 L) was transferred from a Niskin bottle into a pre-washed, soft, polyethylene tank through a pre-washed silicon tube. Water samples $(n=66)$ were filtered through pre-combusted $\left(450{ }^{\circ} \mathrm{C}\right.$ for $\left.4 \mathrm{~h}\right) \mathrm{Grade} \mathrm{GF} / \mathrm{F}$ 
Whatman 47-mm glass fiber filters. Filters were stored in pre-combusted aluminum foil at $-20{ }^{\circ} \mathrm{C}$ for particulate inorganic carbon (e.g., calcium carbonate). The acid was then removed using a vacuum desiccator, and the samples were dried in a convection oven at $60{ }^{\circ} \mathrm{C}$ overnight $(12 \mathrm{~h})$. The filters were packed in tin cups before analysis with an elemental analyzer (FLASH EA1112, Themo Fischer Scientific, USA). Alanine and glutamine acid (FUJIFILM Wako Pure Chemical Corp., Japan, Guaranteed Reagent, assess analyzer stability.

The vertical distributions of POC and backscattering ( $\mathrm{b}_{\mathrm{bp}}$ ) showed similar patterns (Fig. 3ab). Vertical $b_{b p}$ profiles showed spike-like signals in some places that may have reflected the presence of large particles (Bishop and Wood, 2008; Briggs et al., 2011). A linear relationship was found between the POC concentrations and $b_{b p}$ values (Fig. 3c). For this comparison, $b_{b p}$ values were averaged within $\pm 5 \mathrm{~m}$ of each POC sampling depth between the surface and $800 \mathrm{~m}$ to reduce the influence of spiked values. From depths of 800-2000 m, bbp values were averaged within $\pm 10 \mathrm{~m}$ of each POC sampling depth because of the larger intervals between $b_{b p}$ measurement depths.

We used the empirical relationship between POC concentration and $b_{b p}$ based on data from both cruises to estimate POC concentrations for each daily float backscatter profile:

$\operatorname{POC}\left(\mathrm{mmol} \mathrm{C} \mathrm{m} \mathrm{m}^{-3}\right)=\mathrm{b}_{\mathrm{bp}} \times 6278.6-0.2, \quad r^{2}=0.80$

POC $\left(\mathrm{mg} \mathrm{C} \mathrm{m}^{-3}\right)=\operatorname{POC}\left(\mathrm{mmol} \mathrm{C} \mathrm{m}^{-3}\right) \times 12 \mathrm{mg} \mathrm{mmol}^{-1}$

As with the $\mathrm{Chl} a$ concentrations, data in the surface $100 \mathrm{~m}$ at the recovery stations were not used for the estimation of POC concentrations. The ranges of the POC concentrations and $b_{b p}$ values for equation (2) were 1-4 mmol C m${ }^{-3}\left(15-48 \mathrm{mg} \mathrm{C} \mathrm{m}^{-3}\right)$ and 2.1-5.9 $\times 10^{-4}$. Cetinić et al. (2012), who made similar observations in the North Atlantic, reported the following relationship: POC $\left(\mathrm{mg} \mathrm{C} \mathrm{m}^{-3}\right)=b_{b p} \times 43317-$ 18.4. Furthermore, in the Southern Ocean, Rambauvile et al. (2017) and Schallenberg et al. (2019) have 
reported that POC $\left(\mathrm{mmol} \mathrm{C} \mathrm{m}{ }^{-3}\right)=b_{b p} \times 3963.45-0.6$, and POC $\left(\mathrm{mg} \mathrm{C} \mathrm{m}^{-3}\right)=b_{b p} \times 37601-4.95$, respectively. The coefficients in these equations are 30-40\% smaller than the corresponding coefficients calculated in this study. One possible reason for this difference may be that the prior studies focused on subarctic and polar regions inhabited by large phytoplankton, whereas our study was in a relatively oligotrophic subtropical area dominated by small phytoplankton (Fujiki et al., 2015). Small particles are known to be associated with lower bbp index values (Morel and Ahn, 1991) and therefore tend to yield higher coefficients in the POC- $\mathrm{b}_{\mathrm{bp}}$ relationship.

\subsection{Auxiliary data sets}

We used daily mean global eddy-resolving ocean reanalysis data $\left(1 / 12^{\circ}\right.$ horizontal resolution, Global_ReAnalysis_phy_001_030) provided by the Copernicus Marine Environment Monitoring Service (http://marine.copernicus .eu) covering the float observation period.

We used $14^{\circ} \times 1 / 4^{\circ}$ daily gridded sea surface height anomaly (SSHA) data from the Archiving, Validation, and Interpretation of Satellite Oceanographic (AVISO) dataset (Ducet et al., 2000) from CNES and Chl a concentrations from the Moderate Resolution Imaging Spectroradiometer-Aqua (MODIS) satellite level 2 LAC (Local Area Coverage) data from NASA (https://oceancolor.gsfc.nasa.gov/cgi/browse.pl) on 15 March (A2018074031000.L2_LAC_OC.nc), 25 March (A2018084034500.L2_LAC_OC.nc), and 29 March (A2018088032000.L2_LAC_OC.nc).

We also used the ERA5 hourly reanalysis data (1/4 horizontal resolution) from the European Centre for Medium-Range Weather Forecasts (https://www.ecmwf.int/en/forecasts/datasets/reanalysisdatasets/era5) for surface heat fluxes and wind stresses during the observation period.

During the KS-18-1 cruise, one Seaglider (manufactured by iRobot (now moved to Kongsberg), S/N: sg551), equipped with conductivity, temperature, pressure, and DO sensors, was deployed. A part of profiling data was used to describe oceanic condition during the floats' observation period.

\subsection{Heat budget of the upper ocean}


We calculated the temporal changes of heat content and examined the one-dimensional heat budget of the upper ocean. If this heat budget did not balance, we hypothesized that other factors such as float movements and horizontal advection might have caused the imbalance.

Because the mixed layer south of the Kuroshio Extension reaches a depth of 300 dbar, we calculated the heat content between the shallowest observed depth and $400 \mathrm{dbar}$ for the profiles from both floats to avoid estimating entrainment heat fluxes associated with deepening of the mixed layer. In the onedimensional balance, if the vertical heat flux across $400 \mathrm{dbar}$ is negligibly small, the daily heat content change should be equal to the heat flux at the sea surface,

$\left.\rho C_{p} \Delta \int_{-400}^{0} \theta d z \sim \int_{0}^{1 d a y} F_{t}\right|_{z=0} d t$.

Here, $\Delta$ is the difference between two daily profiles and $\left.F_{t}\right|_{z=0}$ is the surface heat flux due to the airsea heat exchange.

To consider the air-sea heat flux, we interpolated hourly float positions between daily positions and then interpolated the ERA5 hourly reanalysis data to those positions. The interpolated hourly heat fluxes were integrated over $24 \mathrm{~h}$ and compared with the daily change of heat content.

\section{Results}

\subsection{Atmospheric and hydrographic conditions}

In this study, we focused on the changes in biological and chemical parameters that occurred during periods of deep mixing and rapid stratification and the times when stratification persisted for several days. In early February, a week or so of strong winds was followed by a few calm days. After mid-February, most of the calm intervals between periods of strong winds exceeded a few days (Fig. 4a). The primary period of mixed layer shoaling occurred during one day when it decreased from $>200 \mathrm{~m}$ to $<70 \mathrm{~m}$ (Fig. 4cd). The start of this event was defined as the time when the mixed layer exceeded $200 \mathrm{~m}$, and the end of the event was defined as the time when the mixed layer became shallower than $70 \mathrm{~m}$. The mixed-layer 
depth was defined to be the shallowest depth at which the density was $0.0125 \mathrm{~kg} \mathrm{~m}^{-3}$ greater than the density at the sea surface (defined to be the average density over the shallowest observed layer to at most 10 dbar; de Boyer Montégut et al. 2004). Four stratification events were detected for each float (Table 1). Because the density changed significantly before the end of events 3 and 4 observed by float 2903329 and event 4 observed by float 2903330, the end date was determined from the change in the density profile.

The average temperature of the water column from the surface to the 400-dbar level (Fig. 4e) increased until 10 March, decreased suddenly just before 11 March, and then started to increase slowly thereafter. Because surface heat fluxes measured in February and March showed cooling of the ocean surface, we hypothesized that the observed increases were likely caused either by lateral advection of warm water or by lateral movement of the floats. The fact that the daily change of heat content was 10 times (or even more) the time-integrated net heat flux (Fig. 4f) underscored the importance of changes due to horizontal temperature gradients. Our results suggested that among the post-storm events that we identified, Case 4 was relatively close to a one-dimensional exchange of heat in the upper $400 \mathrm{dbar}$ of the water column.

Examination of the vertical variation of water temperature from the surface to a depth of $400 \mathrm{~m}$ revealed that the temperature above a depth of $200 \mathrm{~m}$ was higher than $18{ }^{\circ} \mathrm{C}$ until mid-March (Fig. 5ab), and temperature gradually decreased with depth below $200 \mathrm{~m}$ throughout the observation period. When the surface mixed layer deepened in mid-March, the surface temperature dropped to $17.4{ }^{\circ} \mathrm{C}$. At that time, there was a small difference in temperature from the surface to a depth of $400 \mathrm{~m}$. From late March, the temperature near the surface again exceeded $18^{\circ} \mathrm{C}$. A comparison of the two floats revealed that the water temperature observed by float 2903330 exceeded that observed by float 2903329 after March. This pattern reflected the fact that float 2903330 had moved closer to the Kuroshio Extension (Fig.1). The salinity exceeded 34.85 from the surface to a depth of $\sim 200 \mathrm{~m}$ (Fig. 5cd). In addition, a gradual decrease of salinity with depth below 200m was observed throughout the observation period. During Case 1 in early February, the deep mixing temporarily reduced the salinity near the surface. In mid-March, the salinity of the surface layer was lowered by mixing with subsurface water. In late March, the salinity in the surface exceeded 34.85 , and the temperature of the surface water exceeded $18^{\circ} \mathrm{C}$. The high-temperature, low-salinity water seen at the surface at the end of the observation period was influenced by the Kuroshio Extension. 

revealed repeated mixing and stratification between the beginning of the observation period and midMarch (Fig. 5ef). The thickness of the mixed layer varied between $<100 \mathrm{~m}$ and $>200 \mathrm{~m}$, with frequent changes until mid-March. These changes were observed by both floats. The $25.3 \sigma_{\theta}$ contour line, which roughly corresponded to the bottom of the deep mixed layer, gradually deepened over time during this period. The deepest mixed layer was observed on 18 March. Float 2903329 then observed a mixed layer depth $>300 \mathrm{~m}$ almost daily until 25 March. The continuous deepening of the mixed layer exposed 25.3 $\sigma_{\theta}$ water at the sea surface and created a thick layer of subtropical mode water. Meanwhile, float 2903330 recorded that the mixed layer had changed significantly after 18-25 March: it deepened to >300 $\mathrm{m}$ on 25 March and then rapidly shoaled, whereas float 2903329 documented that there was no exposure of the $25.3 \sigma_{\theta}$ water mass. This difference might be because float 2903330 observed water closer to the Kuroshio than float 2903329. Subsequently, the depths of the mixed layer observed by both floats were mostly shallower than $100 \mathrm{~m}$. The temporal variations observed by float 2903329 indicated that the $25.3 \sigma_{\theta}$ water mass was gradually subducted under the euphotic zone after outcropping due to restratification or floats movements. Isothermal heaving was apparent below the mixed layer at various times. We examine below the physical oceanographic conditions during the period of heaving between 11 and 18 March, which corresponded to the period of the third post-storm restratification event (Case 3 in Table 1). In April, the mixed layer shoaled in response to atmospheric conditions, and the positions of the two floats approached the Kuroshio Extension, which caused a rise of isopycnal surfaces at depths of 300-400 m.

\subsection{Temporal variations of biogeochemical parameters}

\subsubsection{DO}

The DO concentration in the water column was high in the euphotic zone and gradually decreased with depth. In addition to mixing and advection, variations in upper ocean DO concentrations can be caused by air-sea exchange of oxygen with the atmosphere in response to changes in water temperatures, the photosynthetic production of oxygen by phytoplankton in the euphotic zone, and the consumption of 
oxygen via respiration. The vertical profiles of DO from the surface to $400 \mathrm{~m}$ showed a temporal change similar to that of density until mid-March (Fig. 6ab). Oxygen was transported to deeper layers with the gradual deepening of the mixed layer during this period. In mid-to-late March, the DO concentration near the surface increased a few days after the deepening of the mixed layer. Atmospheric cooling and lower water temperatures may have caused the DO concentration to increase due to increased solubility and gas exchange. Later, the surface mixed layer was stratified, and the water temperature began to increase, but the DO concentration remained high, perhaps because of photosynthetic production of oxygen in the euphotic zone.

Examination of the time-series profiles of DO percent saturation (Fig. 6cd) revealed changes similar to those of the DO concentrations. By mid-March, the DO was slightly undersaturated in the mixed layer. This undersaturation was likely due to the redistribution of low-DO water from depth into the mixed layer caused by deep mixing. Intermittent DO supersaturation was observed near the surface in late March. These temporal variations of DO saturation imply that photosynthetic production of oxygen actively occurred or that water temperature increased during this period. At depths of 300-400 m, the DO concentration and percent saturation tended to decrease with time in April (Fig. 6a-d) because the isopycnal surface shoaled, and a water mass with a low oxygen concentration was lifted as the Kuroshio Extension was approached.

\subsubsection{Chl $a$}

The concentrations of $\mathrm{Chl} a$ (Fig. 6ef) exceeded $0.1 \mu \mathrm{g} \mathrm{L} \mathrm{L}^{-1}$ from the surface to below the depth of the euphotic zone ( $200 \mathrm{~m}$ ) until mid-March. This Chl $a$ distribution may indicate that phytoplankton in the euphotic zone were transported by frequent vertical mixing to the twilight zone, where they could not photosynthesize because the irradiance was inadequate (below a depth of $200 \mathrm{~m}$ in this study). In early February, Chl $a$ concentrations increased slightly in the euphotic zone after the mixed layer deepened (Fig. 7ab). This increase of Chl $a$ concentrations suggests that even in winter, when mixing events frequently occur, phytoplankton populations begin to increase once active mixing ceases (Siegel et al., 
2002; Behrenfeld 2010; Mahadevan et al., 2012; Lacour et al., 2017; Maúre et al., 2017). A few days after the deepest mixing occurred in March, a higher Chl $a$ fluorescence was observed near the surface. Deep mixing increased nutrient concentrations in the euphotic zone, and the surface water was stratified for a few weeks. These conditions suggest that phytoplankton received a stable supply of light, which led to a high rate of primary production. However, after the floats approached the Kuroshio Extension in April, Chl $a$ values below the euphotic zone were lower than before. The implication is that the vertical distribution of Chl $a$ from winter to spring in the deep mixing area was greatly influenced by mixing in the water column.

\subsubsection{Nitrate}

The vertical profiles of nitrate revealed high concentrations at depths below $200 \mathrm{~m}$ (Fig. 6gh). The nitrate concentration in the euphotic zone was below $2 \mu \mathrm{mol} \mathrm{kg}^{-1}$ for most of the observation period, but there was an increase in mid-March at float 2903329. From late February to mid-March, an increase in nitrate near the surface was observed during the mixing period. The nitrate concentration in the surface layer increased after the mixed layer deepened from mid-March to late March. Subsequently, the nitrate concentrations in the surface layer decreased to concentrations below those found before the mixing events (Fig. 6gh, 7gh). At that time, nitrate concentrations may have limited primary production. At depths of 300-400 m, nitrate concentrations gradually increased in April, likely due to the heaving of high-density water associated with the approach to the Kuroshio Extension.

\subsubsection{POC}

The temporal variation of the POC profiles (Fig. 6ij) was similar to that of the Chl $a$ concentrations (Fig. 6ef), and a similar trend was also observed for the distribution of oxygen percent saturation (Fig. 6cd). The POC concentrations in the euphotic zone exceeded $3 \mu \mathrm{mol} \mathrm{C} \mathrm{kg}^{-1}$ throughout the observation period; they decreased with deepening of the mixed layer and increased during the restratification periods (Fig. $7 \mathrm{~cd})$. The average ratio of $\mathrm{POC}$ to $\mathrm{Chl} a(\mathrm{POC} / \mathrm{Chl} a$ ratio) in the upper $70 \mathrm{~m}$ of the water column varied 
between 30 and $130 \mathrm{~g} \mathrm{C} \mathrm{g}^{-1} \mathrm{Chl} a$ throughout the observation period (Fig. 7ef). These values are within the range of previously reported $\mathrm{C} / \mathrm{Chl} a$ ratios in the North Pacific (30-190 $\mathrm{g} \mathrm{C} \mathrm{g}^{-1} \mathrm{Chl} a$, Behrenfeld et al., 2005).

The POC concentrations just below the euphotic zone (depths of 70-200 m, the upper layer of the twilight zone) varied similarly to those in the euphotic zone until the end of February, after which they were similar to the POC concentrations at depths of 200-300 m (Fig. 8ab). At depths of 200-300 m, the POC concentrations were similar to those at depths of 300-400 m, but the POC concentrations increased at the depths of 200-300m when the depth of the mixed layer exceeded $200 \mathrm{~m}$. In contrast, at depths of 300-400 m, the POC concentrations were $1.5 \pm 0.3 \mu \mathrm{mol} \mathrm{C} \mathrm{kg}-1$ for 2903329 and $1.6 \pm 0.3 \mu \mathrm{mol} \mathrm{C} \mathrm{kg}^{-1}$ for float 2903330 during this study and increased slightly throughout the observation period (Fig. 8ab). The vertical distribution of POC (Fig. 7ij) indicated that the POC concentration was low in the highdensity water that shoaled at depths of 300-400 m in April.

The POC concentrations and their temporal variations in the $\sigma_{\theta} 25.00-25.25$ layer (Fig. 8cd), which included the euphotic zone on many observation days (Fig. 8ef), were similar to the concentrations and temporal variations of the POC in the euphotic zone (Fig. 8ab). In contrast, the POC concentrations in the $\sigma_{\theta}$ 25.25-25.50 layer resembled those in the deeper layers, except when that layer shoaled from early March to early April (Fig. 8ef). In the $\sigma_{\theta}$ 25.50-25.75 and 25.75-26.00 layers, almost all the POC concentrations were $<2 \mu \mathrm{mol} \mathrm{C} \mathrm{kg}^{-1}$ for both floats.

\section{Discussion}

\subsection{Case studies: biogeochemical processes during the transitions from mixing to restratification}

We observed biological activity in the surface mixed layer associated with intermittent mixing and restratification events from winter to spring of 2018. The Chl $a$ concentration in the euphotic zone increased after the deepening and subsequent shoaling of the mixed layer (Fig. 7ab). This increase suggests that vertical mixing in this oligotrophic region transports nutrients (such as nitrate) from the aphotic zone to the surface and thereby increases primary production (reflected by increases of Chl $a$ and 
POC concentrations) when the mixing ceases (Carranza et al., 2018). We analyzed temporal variations of water mass structure and biogeochemical parameters in the euphotic zone and the mixed layer during selected events (Table 1) to reveal the relationship between surface disturbances and biological activities. Here, the temporal variation (rate) of each parameter is shown with + for increases and - for decreases.

\subsubsection{Case 1: 2-4 February (float 2903329) and 7-9 February (float 2903330)} Float 2903329 moved eastward during 2-4 February along the SSHA contour (Fig. 9a). The mixed layer exceeded $200 \mathrm{~m}$ on 2 February and $19 \mathrm{~m}$ on 3 February (Fig. 9b) when winds started to increase but surface cooling had not yet begun. The potential temperature in the mixed layer changed little, and changes of heat content occurred mainly below the 200-dbar level. We therefore considered that the floats observed the same water mass in the mixed layer.

Concentrations of Chl $a$ and POC during this period increased slightly, whereas the concentration of nitrate decreased slightly (Fig. 7acg). The POC/Chl $a$ ratio, which is a metric for the fraction of particles comprised of living phytoplankton, decreased (Fig. 7e, Table 2). The rates of POC increase and nitrate decrease were $+0.28 \mu \mathrm{mol} \mathrm{C} \mathrm{kg}^{-1} \mathrm{~d}^{-1}$ and $-0.08 \mu \mathrm{mol} \mathrm{N} \mathrm{kg}{ }^{-1} \mathrm{~d}^{-1}$, respectively, based on changes of these concentrations in the euphotic zone from the last day of the mixing period to the last day of the stratified period. The rate of increase of organic carbon, estimated from the rate of decrease of the nitrate concentration and the Redfield $\mathrm{C} / \mathrm{N}$ ratio ( 6.6 by atoms), was $+0.53 \mu \mathrm{molC} \mathrm{kg}^{-1} \mathrm{~d}^{-1}$, almost twice as large as the observed rate of increase of the POC. Possible causes of this are that some of the produced organic matter was in the form of dissolved organic carbon (DOC), that zooplankton grazed phytoplankton, and/or that part of the POC sank immediately into the deeper layer $(>70 \mathrm{~m})$ after being produced. February continued until 7 February (Fig. 9c). Then, during 8-9 February, the mixed layer shoaled and warmed. During 8-11 February, a warm front within the mixed layer was identified near the western end of a SeaGlider transect across the float trajectory (Figs. 9a and 10). We therefore concluded that the warmer water encountered by the floats as they drifted westward after deployment represented a different water mass. 
During this period, concentrations of $\mathrm{Chl} a$ and POC increased, whereas nitrate concentrations decreased (Fig. 7bdh). In contrast, the POC/Chl $a$ ratio did not change (Fig. 7f). A comparison of rates of POC increase and nitrate decrease revealed that the latter exceeded the former. In this case, the $\mathrm{C} / \mathrm{N}$ ratio may have differed significantly from the Redfield ratio because different surface water masses were mainly below the 200-dbar level, we concluded that the floats were within the same water mass of the mixed layer above the 200-dbar level.

The rate of increase of the POC concentrations and decrease of the nitrate concentrations were +0.06 $\mu \mathrm{mol} \mathrm{C} \mathrm{kg}{ }^{-1} \mathrm{~d}^{-1}$ and $-0.01 \mu \mathrm{mol} \mathrm{N} \mathrm{kg}{ }^{-1} \mathrm{~d}^{-1}$ for float 2903329 and $+0.24 \mu \mathrm{mol} \mathrm{C} \mathrm{kg}^{-1} \mathrm{~d}^{-1}$ and $-0.04 \mu \mathrm{mol}$ $440 \mathrm{~N} \mathrm{~kg}^{-1} \mathrm{~d}^{-1}$ for float 2903330 (Table 2). The fact that the $\mathrm{C} / \mathrm{N}$ ratio during this period was close to the Redfield ratio likely indicates that there was little exchange between the water in the euphotic zone and the surrounding water mass(es). The $\mathrm{POC} / \mathrm{Chl} a$ ratio decreased from the mixing period to the restratification period. The high $\mathrm{POC} / \mathrm{Chl} a$ ratio during the mixing period was probably due to the recruitment of particles with high $\mathrm{POC} / \mathrm{Chl} a$ ratios from below the euphotic zone, and the low ratio during the re-stratification period was likely due to the increase of the phytoplankton biomass. It is unclear why float 2903330 recorded rates of POC increase and nitrate decrease that were four times those of float 2903329. 


\subsubsection{Case 3: 6-14 March (float 2903329) and 7-16 March (float 2903330)}

The deep mixing continued for several days until 8 March, and the restratification period lasted for about one week starting on 9 March. While the floats moved westward roughly along the SSHA contour during this period (Fig. 12ab), a cyclonic feature moved northward through the area, and the floats recorded a doming isotherm (Fig. 5) below the mixed layer (Fig. 12c). The isopycnal surfaces at depths of 200-400 $\mathrm{m}$ became uniformly shallower. It can be inferred from the time series of nitrate profiles (Fig. 6gh) that eddy upwelling supplied nutrients from the twilight layer to the euphotic zone. The doming isotherm was also accompanied by salinity intrusions (Fig. 12d), which disappeared when the floats left the doming structure. This mesoscale doming and the accompanying salinity intrusions indicates the importance of lateral processes associated with a cyclonic feature.

During this period, the rate of increase of POC was $+0.4 \mu \mathrm{mol} \mathrm{C} \mathrm{kg}^{-1} \mathrm{~d}^{-1}$ (Table 2, Fig. 7cd). In contrast, the nitrate concentrations recorded by float 2903330 barely decreased, whereas those recorded by float 2903329 increased (Fig. 7gh). This difference was caused by the fact that the floats moved from the edge of the cyclonic eddy toward the center, so that isopycnal surfaces and the nitracline shoaled. The POC/Chl $a$ ratios were high at the edge of the eddy and decreased toward the center (Fig. 7ef).

\subsubsection{Case 4: 21-28 March (float 2903329) and 25-28 March (float 2903330)}

The northward movement of the floats during the time interval of Case 4 was related to the cyclonic structure of the large-scale circulation (Fig. 13ab). We observed the deepest mixed layer ( 320 dbar) during this period, and potential temperature in the water column within the mixed layer was relatively uniform and then gradually stratified (Fig. 13cd). Case 4 was associated with the largest increases of Chl $a$ and POC among the four events (Fig. 7a-d). The increase of the POC might have been due to the poststorm formation of submesoscale cyclonic eddies in the mixed layer (Fig. 14), which trapped nutrients and phytoplankton near the surface during the relatively calm, warm weather. The deepening of the mixed layer ended on 25 March, and the restratification period lasted for 6 days from 26 March (Table 1). 
It was determined that Case 4 ended on 28 and 27 March for float 2903329 and 2903330, respectively the horizontal gradient of buoyancy. The $Q$ vector (e.g., Hoskins et al., 1978) is defined as

$$
\boldsymbol{Q}=\left(Q_{1}, Q_{2}\right)=\left(-\frac{\partial u}{\partial x} \frac{\partial b}{\partial x}-\frac{\partial v}{\partial x} \frac{\partial b}{\partial y},-\frac{\partial u}{\partial y} \frac{\partial b}{\partial x}-\frac{\partial v}{\partial y} \frac{\partial b}{\partial y}\right)
$$


We calculated the above variables by using ocean reanalysis data (described in Section 2.2) that did not was also important for the restratification as well as biological activities in Case 4 because the intervals between storms were longer in late winter, and the satellite data (Fig. 14) showed high surface concentrations of Chl $a$ within submesoscale cyclonic eddies at that time. 


\subsection{Degradation and sinking processes of POC in the twilight zone}

The transport and degradation of POC formed in the euphotic zone may be observed in the temporal variation of POC concentrations at $\sigma_{\theta}$ values of 25.25-25.50 (Fig. 8c-f). This density layer sank from the surface layer to the twilight layer on 25 March for float 2903329 and on 27 March for float 2903330. The water mass with a $\sigma_{\theta} 25.31$ stayed at a depth of $200-300 \mathrm{~m}$ for several days, during which the rate of POC decrease was estimated to be $-0.09 \mu \mathrm{mol} \mathrm{C} \mathrm{kg}{ }^{-1} \mathrm{~d}^{-1}$ for float 2903329 and $-0.05 \mu \mathrm{mol} \mathrm{C} \mathrm{kg}^{-1} \mathrm{~d}^{-1}$ for float 2903330 (Table 3). In contrast, the rates of decrease of DO were estimated to be $+0.02 \mu$ mol $\mathrm{O}_{2}$ $\mathrm{kg}^{-1} \mathrm{~d}^{-1}$ (i.e., an increase) for float 2903329 and $-0.62 \mu \mathrm{mol} \mathrm{O} \mathrm{kg}^{-1} \mathrm{~d}^{-1}$ for float 2903330 . The rate of DO consumption in the vicinity of our study area has been reported to be $-0.5 \mu \mathrm{mol} \mathrm{O}_{2} \mathrm{~kg}^{-1} \mathrm{~d}^{-1}$ (Sukigara et al., 2019), which is close to the rate recorded by float 2903330 . Both floats recorded a decrease of nitrate concentrations during this period (Table 3); an increase of nitrate concentrations due to degradation of OM was thus not observed. The predicted increase in nitrate during this period is not large $(\sim+0.2 \mu \mathrm{mol}$ $\mathrm{N} \mathrm{kg}^{-1}$ ), so it may be not detected by the current sensitivity of the sensor. If the oxygen decrease observed by float 2903330 was due to the degradation of OM, the expected rate of POC decrease based on Redfield stoichiometry was larger than the observed rate of POC decrease. The explanation may be that the substrate for degradation included not only autochthonous POC, but also DOC in this layer and POC newly added to this layer by fragmenting from particles settling from the euphotic layer.

The POC concentrations at depths of 300-400 m were almost unchanged for both floats throughout the observation period. This suggests that most of the OM in the euphotic zone was decomposed at shallower depths. Both floats, however, recorded average POC concentrations at depths of 300-400 m during $22-$ 31 March $\left(1.8 \mu \mathrm{mol} \mathrm{C} \mathrm{kg}{ }^{-1}\right.$ for float 2903329 and $1.9 \mu \mathrm{mol} \mathrm{C} \mathrm{kg}^{-1}$ for float 2903330) that were a little higher than those during 1-10 February $\left(1.2 \mu \mathrm{mol} \mathrm{C} \mathrm{kg}^{-1}\right)$. These increases in POC concentrations may have been due to slowly sinking particles. If this increased concentration $\left(0.65 \mu \mathrm{mol} \mathrm{C} \mathrm{kg}^{-1}\right)$ was the average value for this study area, the POC concentrations at depths of 300-400 m would increase by 65 mmol C in two months. The POC flux at a depth of $300 \mathrm{~m}$ can be estimated to be $1.1 \mathrm{mmol} \mathrm{C} \mathrm{m}^{-2} \mathrm{~d}^{-1}$ 
(13.1 $\left.\mathrm{mg} \mathrm{C} \mathrm{m}^{-2} \mathrm{~d}^{-1}\right)$. This estimated flux is about one-third of the flux of sinking POC (42.1 $\mathrm{mg} \mathrm{C} \mathrm{m}^{-2}$ $\mathrm{d}^{-1}$, Honda et al., 2016) at a depth of $200 \mathrm{~m}$ observed by the drifting sediment trap at station S1. Our estimate may be an underestimate of the POC flux at that depth because it does not include particles that settle from a depth of $400 \mathrm{~m}$ to greater depths, and it ignores particles that decompose at depths of 300 $400 \mathrm{~m}$. The implication is that the contribution of particles estimated in this study is not a negligible fraction of the POC flux at a depth of $300 \mathrm{~m}$ during the winter and spring in this region.

\section{Conclusion}

Two BGC Argo floats equipped with oxygen, chlorophyll fluorescence, backscatter, and nitrate sensors revealed the temporal changes in biological activity associated with the disturbance and restratification of the ocean surface layer caused by the passage of storms in the subtropical western North Pacific during winter and spring. A time series of the vertical profile of the POC concentration was obtained from the backscatter sensor by calibrating the sensor with the POC concentrations measured during water sampling.

During the observation period, mixing of surface water due to cooling and subsequent restratification occurred repeatedly. Four mixing-restratification events were detected by each float, and enhancement of Chl $a$ concentrations was observed during the restratification phase of all events. Because Argo floats do not always track the same water mass, we determined whether the observed phenomena were occurring within the same water mass based on the water mass structure, heat flux, and SSHA. Our analyses indicated that cases 1, 2, and 4 for float 2903329 and cases 2 and 4 for float 2903330 were events that occurred in the same water mass. In those cases, POC concentrations increased and nitrate concentrations decreased during the restratification phase, and the $\mathrm{C} / \mathrm{N}$ ratios were close to or slightly lower than the Redfield ratio. The reason for the relatively (to Redfield) low $\mathrm{C} / \mathrm{N}$ ratios may have been that only suspended POC could be observed by the backscatter sensor in this study, and DOC and fast-sinking POC produced by primary production were not included. The $\mathrm{C} / \mathrm{Chl} a$ ratio tended to decrease during the restratification period compared to the mixing period in most of these cases. This pattern suggests that production of organic matter was taking place in the euphotic zone after mixing with subsurface water containing particles with high $\mathrm{C} / \mathrm{Chl} a$ ratios. During the restratification period of Case 4 , a significant 
increase of Chl $a$ and POC concentrations and an equivalent decrease in nitrate were observed in the euphotic zone within a few days. These changes were caused by deep mixing that alleviated nutrient limitation prior to stratification alleviating light limitation. In addition, the floats were located at the edge of a mesoscale cyclonic feature, and the heaved isopycnal surface may also have contributed to the increased nutrient availability. The largest rate of POC increase, $+210 \mathrm{mmol} \mathrm{C} \mathrm{m}^{-2} \mathrm{~d}^{-1}\left(+2520 \mathrm{mg} \mathrm{m}^{-2}\right.$ $\mathrm{d}^{-1}$ ) during Case 4, was observed by float 2903330. This rate of POC increase was larger than the rate of net primary production reported in this area. The results of this study indicate that intense biological activity events, although short lived and highly localized, occur repeatedly in the western North Pacific subtropical region during winter and spring. There is also a suggestion that cyclonic features increase the nutrient concentrations in the euphotic zone and enhance primary productivity.

In this study, we were also able to use BGC floats to observe biological activities and material transport in the twilight layer. When the mixed layer deepened, concentrations of $\mathrm{Chl} a$, oxygen, nitrate, and POC became uniform in the mixed layer. Concentrations of POC in the twilight layer then decreased as mixing stopped. Decreases of POC $\left(-0.05\right.$ to $\left.-0.09 \mu \mathrm{mol} \mathrm{C} \mathrm{kg}^{-1} \mathrm{~d}^{-1}\right)$ were observed in the density range of $\sigma_{\theta}$ 25.25-25.50 that were exposed to the surface and then capped by less dense waters and isolated below the euphotic zone. Decreases of oxygen $\left(-0.62 \mu \mathrm{mol} \mathrm{O} \mathrm{kg}^{-1} \mathrm{~d}^{-1}\right)$ were also observed for float 2393330; however, the estimated POC consumption based on Redfield stoichiometry exceeded the observed POC decreases. A possible explanation is that the substrate for the decomposition contained not only POC but also DOC, which cannot be observed by a backscatter sensor. At depths below the mixed layer (300-400 $\mathrm{m})$, the averaged POC concentrations increased slightly throughout the observation period. This rate of increase could be attributed to a flux of slowly sinking particles at depths of $\sim 300 \mathrm{~m}$. The estimated rate was $1.1 \mathrm{mmol} \mathrm{C} \mathrm{m}^{-2} \mathrm{~d}^{-1}$, which is one-third of the sinking flux estimated by sediment traps in a neighboring area. Most organic matter, whether particulate or dissolved, that accumulated in the euphotic layer during the deep mixing and subsequent restratification events was decomposed at depths shallower than the winter mixed layer $(\sim 300 \mathrm{~m})$ and will likely be re-entrained the following winter. However, the particles that sunk deeper than $300 \mathrm{~m}$ may be exported and isolated from the atmosphere on the longer 
time scale. In the future, particle observation with many BGC Argo floats would be essential to accurately estimate the flux of particles sinking deeper than the winter mixed layer.

BGC Argo floats have enabled high temporal and spatial resolution measurements of BGC parameters that were previously observed only discretely by onboard water sampling observations. This capability allowed us to quantitatively evaluate the processes of particle (1) production, (2) decomposition, and (3) transport to depth. It is also clear that these processes are greatly influenced by the mesoscale structure of the ocean and transient weather changes. The use of two floats in this study also revealed differences in biological activity that depended on the position of the float. Our results suggested that mixing and restratification events are spatially heterogenous, so sustained, high-frequency, and spatially distributed floats observations are needed to quantify how important the winter-spring transition is to annual carbon export regionally.

\section{Acknowledgement}

We thank the captain, crew, and scientists of R/V Shinsei-maru of the Japan Agency for Marine-Earth Science and Technology (JAMSTEC). We also thank S. Oshitani, K. Katayama, and H. Tamada at Marine Works Japan Ltd. for their analysis and deck work. We appreciate M. Murata for the nutrient analysis. This experiment was supported by a Grant-in-Aid for Scientific Research on Innovative Areas (Ministry of Education, Culture, Sports, Science and Technology (MEXT) KAKENHI JP15H05818 and JP15K21710). T. Nagai was supported by a Grant-in-Aid for Scientific Research (MEXT KAKENHI JP16H01590, JP18H04914, JP19H01965, and JP20K20634). A. J. Fassbender and Y. Takeshita were supported by the David and Lucile Packard Foundation/MBARI.

\section{References}

Alldredge, A. L., Silver, M. W.: Characteristics, dynamics and significance of marine snow. Progress in Oceanography, 20 (1), 42-82, doi:10.1016/0079-6611(88)90053-5, 1988. 
Alonso-González, I. J., Arístegui, J., Lee, C., Sanchez-Vidal, A., Calafat, A., Fabrés, J., Sangrá, P., Masqué, P., Hernández-Guerra, A., Benítez-Barrios, V.: Role of slowly settling particles in the ocean carbon cycle. Geophysical Research Letters, 37, L13608, doi:10.1029/2010GL043827, 2010.

Armstrong, R. A., Peterson, M. L., Lee, C., Wakeham, S. G.: Settling velocity spectra and the ballast ratio hypothesis. Deep-Sea Research II, 56, 1470-1478, 2009.

Behrenfeld, M. J.: Abandoning Sverdrup's Critical Depth Hypothesis on phytoplankton blooms. Ecology, $91(4), 977-989,2010$.

Behrenfeld, M. J., Boss, E., Siegel, D. A., Shea, D. M.: Carbon-based ocean productivity and phytoplankton physiology from space. Global Biogeochemical Cycles, 19, GB1006, doi:10.1029/2004GB002299, 2005.

Billet, D. S. M., Lampitt, R. S., Rice, A. L., Mantoura, R. F. C.: Seasonal sedimentation of phytoplankton to the deep sea benthos. Nature, 302, 520-522, doi:10.1038/302520a0, 1983.

ALOHA and K2 sites. Deep-Sea Research I, 55, 1684-1706, doi:10.1016/j.dsr.2008.07.012, 2008.

Boyd, P. B., Claustre, H., Lévy, M., Siegel, D. A., Weber, T.: Multi-faceted particle pumps drive carbon sequestration in the ocean. Nature, 568, 327-335, doi:10.1038/s41586-019-1098-2, 2019.

Briggs, N., Perry, M. J., Cetinić I., Lee, Craig, D’Asaro, E., Gray, A. M., Rehm, E.: High-resolution observations of aggregate flux during a sub-polar North Atlantic spring bloom. Deep-Sea Research I. 58, 1031-1039, doi:10.1016/j.dsr.2011.07.007, 2011.

Briggs, N., Dall'Olmo, Claustre, H.: Major role of particle fragmentation in regulating biological sequestration of CO2 by the oceans. Science, 367, 791-793, doi:10.1126/science aay1790, 2020.

Buesseler, K. O., Antia, A. N., Chen, M., Fowler, S. W., Gardner, W. D., Gustafsson, O., Harada, K., Michaels, A. F., Rutgers van der Loeff, M., Sarin, M., Steinberg, D. K., Trull, T. W.: An assessment of the use of sediment traps for estimating upper ocean particle fluxes. Journal of Marine Research, 65 (3), 345-416, 2007. 
Carranza, M. M., Gille, S. T., Franks, P. J. S. S., Johnson, K. S., Pinkel, R. and Girton, J. B.: When Mixed Layers Are Not Mixed. Storm-Driven Mixing and Bio-optical Vertical Gradients in Mixed Layers of the

Southern Ocean. J. Geophys. Res.: Oceans, 123(10), 7264-7289, doi:10.1029/2018JC014416, 2018.

Cetinić I., Perry, M. J., Briggs, N. T., Kallin, E., D’Asaro, E. A., Lee, C. M.: Particulate organic carbon and inherent optical properties during 2008 North Atlantic Bloom Experiment. Journal of Geophysical Research, 117, C06028, doi:10.1029/2011JC007771, 2012.

Dall'Olmo, G., Mork, K. A.: Carbon export by small particles in the Norwegian Sea. Geophysical

Research Letters, 41, 2921-2927, doi:10.1002/2014GL059244, 2014.

Dall'Olmo, G., Dingle, J., Polimene, L., Brewin, R. J. W., Claustre, H.: Substantial energy input to the mesopelagic ecosystem from the seasonal mixed-layer pump. Nature Geoscience, 9, 820-823, doi:10.1038/NGEO2818, 2016.

de Boyer Montégut, C., G. Madec, A. S. Fischer, A. Lazar, and D. Iudicone.: Mixed layer depth over the global ocean: An examination of profile data and a profile-based climatology. J. Geophys. Res.: Oceans, 109, C12003. doi: 10.1029/2004JC002378, 2004.

Ducet, N., Le Traon, P. Y., and Reverdin, G.: Global high-resolution mapping of ocean circulation from the combination of T/P and ERS-1/2, J. Geophys. Res., 105, 19477-19498, 2000.

Fujiki, T., Sasaoka, K., Matsumoto, K., Wakita, M., Mino Y.: Seasonal variability of phytoplankton community structure in the subtropical western North Pacific. Journal of Oceanography, 72, 343-358. https://doi:10.1007/s10872-015-0346-9, 2015.

Gardner, W. D., Chung, S. P., Richardson, M. J., Walsh, I. D. (1995). The oceanic mixed layer pump. Deep-Sea Research II, 42 (2-3), 757-775.

Giering, S. L. C., Humphreys, M. P.: “Biological Pump," in Encyclopedia of Geochemistry, Encyclopedia of Earth Sciences Series, ed W. White. (Cham: Springer), 1-6. doi: 10.1007/978-3-319-39193-9_154-1, 2018.

Giering, S. L. C., Cavan, E. L., Basedow, S. L., Briggs, N., Burd, A., Darroch, L. J., Guidi, L., Irisson, J. Iversen, M. H., Kiko, R., Lindsay, D., Marcolin, C. R., McDonnell, A. M. P., Möller, K. O., Passow, U., 
Thomalla, S., Trull, T. W., Waite, A. M.: Sinking organic particles in the ocean - Flux estimates from in situ optical devices. Frontiers in Marine Science, 6, 1-23, doi:10.3389/fmars.2019.00834, 2020.

Hanawa, K., Talley, L. D.: Mode waters. In Siedler G, Church J, Gould J (eds) Ocean Circulation and Climate: Observing and Modeling the Global Ocean, Academic Press, London, UK, pp 373-386, 2001. Honda, M. C., Kawakami, H., Matsumoto, K., Fujiki, T., Mino, Y., Sukigara, C., Kobari, T., Uchimiya, M., Kaneko, R., Saino, T.: Comparison of sinking particles in the upper $200 \mathrm{~m}$ between subarctic station K2 and subtropical station S1 based on drifting sediment trap experiments. Journal of Oceanography., 72, 373-386. doi: 10.1007/s10872-015-0280-x, 2016.

Hoskins, B. J., Draghici, I., Davies, H. C.: A new look at the $\omega$-equation, Quart. J. R. Met. Soc., 104, 31$38,1978$.

Iversen, M. H., Nowald, N., Ploug, H., Jackson, G. A., Fischer, G.: High resolution profiles of vertical particulate organic matter export off Cape Blanc, Mauritania: Degradation processes and ballasting effects. Deep-Sea Research I, 57, 771-784, 2010.

Grasshoff, K.: Methods of seawater analysis. Verlag Chemie, Weinheim, Germany, and New York, $317 \mathrm{pp}, 1976$.

Johnson, K., O. Pasquenron de Fommervault, R. Serra, F. D’Ortenzio, C. Schmechtig, H. Claustre, and A. Poteau: Processing Bio-Argo nitrate concentration at the DAC level. http://dx.doi.org/10.13155/46121, 2016

Johnson, K. S., Plant, J. N., Coletti, L. J., Jannasch, H. W., Sakamoto, C. M., Riser, S. C., Swift, D. D., Williams, N. L., Boss, E., Haëntjens, Tally, L. D., Sarmiento, J. L.: Biogeochemical sensor performance in the SOCCOM profiling float array. Journal of Geophysical Research (Oceans), 122 (8), 6416-6436, doi:10.1002/2017JC012838, 2017.

Kwon E. Y., Primeau, F. W., Sarmiento, J. L.: The impact of remineralization on the air-sea carbon balance. Nature Geoscience, 2 (9), 630-635, doi:10.1038/ngeo612, 2009.

Lacour L., Ardyna, M., Stec, K. F., Claustre, H., Prieur, L., Poteau, A., D’Alcala, M. R., Iudicone, D.: Unexpected winter phytoplankton blooms in the North Atlantic subpolar gyre. Nature Geoscience, 10 (11), 836-839, doi:10.1038/NGEO3035, 2017. 
Lacour L., Briggs, N., Claustre, H., Ardyna, M., Dall'Olmo, G.: The intraseasonal dynamics of the mixed layer pump in the subpolar North Atlantic Ocean: A biogeochemical-Argo float Approach. Global Biogeochemical Cycles, 33, 266-281, doi:10.1029/2018GB005997, 2019.

Mahadevan, A, D’Asarom E., Lee, C., Perry, M. J.: Eddy-driven stratification initiates North Atlantic spring phytoplankton blooms. Science, 337, 54-58, doi:10.1126/science.1218740, 2012.

Matsumoto, K., Abe, O., Fujiki, T., Sukigara, C., Mino, Y.: Primary productivity at the time-series stations in the northwestern Pacific Ocean: is the subtropical station unproductive? Journal of Oceanography, 72, 359-371, doi:10.1007/s10872-016-0354-4, 2016.

Maúre, E. R., Ishizaka, J., Sukigara, C., Mino, Y., Aiki, H., Matsuno, T., Tomita, H., Goes, J. I., Gomes, Sea. Geophysical Research Letters, 44 (21), 11115-11124, doi:10.1002/2017GL074359, 2017.

Maurer, T. L., Plant, J. N., Johnson, K. S., Delayed-Mode Quality Control of Oxygen, Nitrate, and pH Data on SOCCOM Biogeochemical Profiling Floats: Frontiers in Marine Science, 8, 683207, doi: 10.3389/fmars.2021.683207, 2021.

McGillicuddy, D. J., Robinson, A. R., Siegel, D. A., Jannasch, H. W., Johnson, R., Dickey, T. D., McNeil, J., Michaels, A. F., and Knap, A. H.: Influence of mesoscale eddies on new production in the Sargasso Sea, Nature, 394, 263-266, 1998.

Morel, A., Ahn, Y. H.: Optics of heterotrophic nanoflagellates and ciliates: A tentative assessment of their scattering role in oceanic waters compared to those of bacterial and algal cells. Journal of Marine Research, 49, 177-202, doi:10.1357/002224091784968639, 1991.

Ploug, H. Iversen, M., Fischer, G.: Ballast, sinking velocity, and apparent diffusivity within marine snow and zooplankton fecal pellets: Implication for substrate turnover by attached bacteria. Limnology and Oceanography, 53, 1878-1886, 2008.

Price, J. F., Weller, R. A., Pinkel, R.: Diurnal cycling: Observation and models of the upper ocean response to diurnal heating, cooling and wind mixing. Journal of Geophysical Research, 91(C7), 84118427, doi.org/10.1029/JC091iC07p08411, 1986. 
Qiu, B., Hacker, P., Chen, S., Donohue, K. A., Watts, D. R., Mitsudera, H., Hogg, N. G., Jayne, S. R.: Observation of the subtropical Mode Water evolution from the Kuroshio extension system study. Journal of Physical Oceanographer, 36, 457-473, doi.org/10.1175/JPO2849.1, 2006.

Qiu, B., Chen, S., Hacker, P.: Effect of mesoscale eddies on Subtropical Mode Water variability from the Kuroshio Extension System Study (KESS). Journal of Physical Oceanographer, 37, 982-1000, doi.org/10.1175/JPO3097.1, 2007.

Rembauvill, M., Briggs, N., Ardyna, M., Uitz, J., Catala, P., Penkerch, C., Poteau, A., Claustre, H., Blain, S.: Plankton assemblage estimated with BGC-Argo floats in the Southern Ocean: Implications for seasonal successions and particle export. Journal of Geophysical Research, 122 (10), 8278-8292, doi:10.1002/2017JC013067, 2017.

Resplandy, L., Lévy, M., McGillicuddy, D. J.: Effect of Eddy-Driven subduction on ocean biological carbon pump. Global Biogeochemical Cycles, 33 (8), 1071-1084, doi:10.1029/2018GB006125, 2019.

Sarmiento, J. L., Gruber, N.: Ocean Biogeochemical Dynamics. Princeton University Press, New Jersey, pp.528, 2006.

Sanders, R., Henson, S., Koski, M., De La Rocha, C. L.: The biological carbon pump in the North Atlantic. Progress in Oceanography, 129, 200-218, doi:10.1016/j.pocean.2014.04.005, 2014.

Schallenberg C., Harley, J. W., Jansen, P., Davies, D. M., Trull, T. W.: Multi-year observations of fluorescence and backscatter at the Southern Ocean Time Series (SOTS) shed light on two distinct seasonal bio-optical regimes. Frontiers in marine Science, 6, 595, doi:10.3389/fmars.2019.00595, 2019.

Siegel, D. A., Doney, S. C., Yoder, J. A.: The North Atlantic Spring Phytoplankton Bloom and Sverdrup's Critical Depth Hypothesis. Science, 296, 730-733, doi:10.1126/science.1069174, 2002.

Sukigara, C., Suga, T., Saino, T., Toyama, K., Yanagimoto, D., Hanawa, K., Shikama, S.: Biogeochemical evidence of large diapycnal diffusivity associated with the subtropical mode water of the

North Pacific. Journal of Oceanography, 67, 77-85, doi: 10.1007/s10872-011-0008-5, 2011.

Sukigara, C., Mino, Y., Kawakami, H., Honda, M. C., Fujiki, T., Matsumoto, K., Wakita, M., Saino, T.: Sinking dynamics of particulate matter in the subarctic and subtropical regions of the western North Pacific. Deep-Sea Research I, 144, 17-27, doi:10.1016/j.dsr.2018.11.004, 2019. 
Takeshita, Y., Martz, T. R., Johnson, K. S., Plant, J. N., Gilbert, D., Riser, S. C., Neill, Craig, Tilbrook, B.: A climatology-based quality control procedure for profiling float oxygen data. Journal of Geophysical Research (Oceans), 118, 5640-5650, doi:10.1002/jgrc.20399, 2013.

Tandon, A. and C. Garrett. Geostrophic Adjustment and Restratification of a Mixed Layer with Horizontal Gradients above a Stratified Layer, Journal of Physical Oceanography, 25(10), 2229-2241. doi: 10.1175/JPO-D-17-0219.1, 1995.

Thierry, V., H. Bittig, D. Gilbert, T. Kobayashi, K. Sato, and C. Schmid: Processing Argo OXYGEN data at the DAC level, v2.3.1, http://dx.doi.org/10.13155/39795, 2018.

Turner, J. T.: Zooplankton fecal pellets, marine snow, and sinking phytoplankton blooms. Aquatic Microbiological Ecology, 27, 57-102, doi:10.3354/ame027057, 2002.

Volk, T., and M. I. Hoffert. 1985. OceanVolk, T., Hoffert, M. I.: Ocean carbon pumps: analysis of relative strengths and efficiencies in ocean-driven atmospheric CO2 changes. pp. 99-110. In: E. Sundquist and W. S. Broecker, (Eds.), The carbon cycle and atmospheric CO2: Natural variations archean to present. AGU, pp. 99-110, 1985.

Wenegrat, J. O., L. N. Thomas, J. Gula, and J. C. McWilliams. Effects of the submesoscale on the potential vorticity budget of ocean mode waters. J. Phys. Oceanogr. 48, 9, 2141-2165, 2018.

Wilson, S. E., Steinberg, D. K., Buesseler, K. O.: Change in faecal pellet characteristics with depth as indicators of zooplankton repackaging of particles in the mesopelagic zone of the subtropical and subarctic North Pacific Ocean. Deep-Sea Research II, 55, 1636-1647, doi:10.1016/j.dsr2.2008.04.019, 2008.

Wong, A., R. Keeley, T. Carval and the Argo Data Management Team: Argo Quality Control Manual for CTD and Trajectory Data, http://dx.doi.org/10.13155/33951, 2020.

Xing, X., Wells, M. L., Chen, S., Lin, S. and Chai, F.: Enhanced Winter Carbon Export Observed by BGC-Argo in the Northwest Pacific Ocean, Geophys. Res. Lett., 47(22), doi:10.1029/2020GL089847, 2020. 
Figure 1. Map of the study area showing the two Argo float trajectories (black circles: Argo 2903329; open circles: Argo 290330) and R/V Shinsei-maru CTD stations where water samples were collected (open diamonds).

Figure 2. The relationship between fluorescence measured by floats and $\mathrm{Chl} a$ concentrations from water samples. Black and open circles show measurements from the first profiles of Argo floats 2903329 and 2903330 vs Chl $a$ concentrations. Red open triangles show measurements from the final profile of Argo float 2903330 vs Chl $a$ concentrations. The black line shows the linear fit to data without the four outliers (red open triangles).

Figure 3. (a) Optical backscatter (bbp, $700 \mathrm{~nm}$ ) from the first profile of Argo floats 2903329 and 2903330 and POC sampled on the same day at the float deployment site during the KS-18-1 cruise. Black circles show measured POC concentrations. Black and gray lines show b bp profiles of Argo float 2903329 and 2903330, respectively. (b) $b_{b p}$ from the final profile of Argo float 2903329 and POC sampled on the same day at the float recovery site during KS-18-4 cruise. (c) The relationship between bo and POC. Black and open circles show measurements from the first profile of Argo float 2903329 and 2903330 vs POC concentrations. Black and red open triangles show measurements from the final profile of Argo float 2903329 vs POC concentrations. The black line shows the linear fit to data without the six outliers (red open triangles).

Figure 4. (a) Hourly wind stress and (b) heat flux at float positions. Hourly float positions were linearly interpolated between daily positions. Blue solid and red dashed lines indicate data for floats 2903329 and 2903330, respectively. Thick red and blue lines in (b) show 24-h running averages. Negative values represent surface cooling. Mixed layer depth for floats (c) 2903329 and (d) 2903330. (e) Average potential temperature $(\theta)$ above 400 dbar. Blue and red lines indicate floats 2903329 and 2903330, respectively. (f) Change of heat content (blue line for float 2903329 and red dashed line for float 2903330) and surface heat flux (black solid line). Blue and red lines at the top or bottom of each plot mark the periods of the post-storm restratification events shown in Table 1. 
Figure 5. Time-series of vertical profiles of $(a, b)$ temperatures, $(c, d)$ salinities, and (e, f) potential densities $\left(\sigma_{\theta}\right)$ observed by Argo floats 2903329 and 2903330. Bold lines in e and f indicate the depth of the mixed layer. Broken lines in e and $\mathrm{f}$ indicate the depth of the euphotic layer $(70 \mathrm{~m})$.

Figure 6. Time-series of vertical profiles of $(a, b)$ oxygen concentrations, $(c, d)$ oxygen saturation ratios, (e, f) Chl a concentrations, (g, h) nitrate concentrations, (i, j) Particulate organic carbon (POC) concentrations observed by Argo floats 2903329 and 2903330. Bold lines indicate the depth of the mixed layer. Broken lines indicate the depth of the euphotic layer $(70 \mathrm{~m})$.

Figure 7. Time-series of the euphotic layer (0-70 m) averaged (a, b) Chl $a$, (c, d) POC, (e, f) C/Chl $a$ ratio, and $(\mathrm{g}, \mathrm{h})$ nitrate concentrations observed by floats 2903329 and 2903330.

Figure 8. Time-series of $(a, b)$ average POC concentration in each depth range and $(c, d)$ average POC concentration in each density range observed by floats 2903329 and 2903330 . (e, g) Time-series showing the depths and thicknesses of each density range. Red, orange, green, and blue symbols indicate the $\sigma_{\theta}$ ranges of $25.00-25.25,25.25-25.50,25.50-25.75$, and $25.75-26.00$, respectively. White lines in e and $f$ indicate the depth of the euphotic layer $(70 \mathrm{~m})$.

Figure 9. (a) SSHA contours on 7 February and BGC float trajectories (blue and red dashed lines indicate floats 2903329 and 2903330, respectively). Solid and dashed lines are positive and negative SSHA, respectively, and the contour interval is $0.05 \mathrm{~m}$. Blue and red asterisks are daily float positions for the period of Case 1. The magenta line shows the trajectory of the SeaGlider between 7 and 10 February, and the magenta circles are observation positions between 7 and 9 February. (b) Vertical profiles from 2 to 4 February of potential temperature from float 2903329 and (c) from 7 to 9 February from float 2903330.

Figure 10. Time series of vertical profiles of potential temperature from SeaGlider data. A fixed time (the start of profiling) was used to generate the figure.

Figure 11. Same as Figure 9, but for Case 2. SSHA contours in (a) are for 20 February. Asterisks in (a) are BGC float profiling positions during Case 2. Vertical profiles of potential temperature in (c) are for 17-21 February and (d) 14-21 February. 
Figure 12. Same as Figure 9, but for Case 3. (a) and (b) SSHA contours for 8 and 13 March, respectively. (c) and (d) Vertical profiles on alternate days from 6 to 14 March of potential temperature and salinity, respectively, from BGC float no. 2903329.

Figure 13. Same as Figure 9, but for Case 4. (a) and (b) SSHA contours for 22 and 27 March, respectively. 21 to 23 March of potential temperature from BGC float 290330.

Figure 14. SSHA contours and sea surface chlorophyll $a$ concentrations ( $\mathrm{mg} \mathrm{m}^{-3}$, color scale) derived from satellite data on (a) 15 March, (b) 25 March, and (c) 29 March. Solid and dashed lines are positive and negative, respectively. Contour interval is $0.05 \mathrm{~m}$. The magenta circles and triangles show the positions of BGC floats 2903329 and 2903330, respectively. Storms (see Table 1 and Fig. 2) passed through this area on 7 March (before Case 3) and 21 March (before Case 4).

Figure 15. Horizontal distributions of $(\mathrm{a}-\mathrm{c})$ the normalized $\boldsymbol{Q}$ vector, $10^{13} \times Q \cdot \frac{\nabla_{h} b}{\left|\nabla_{h} b\right|}$, and (d-f) the horizontal divergence of the $\boldsymbol{Q}$ vector, $10^{17} \times-\nabla_{h} \cdot Q$, at $380 \mathrm{~m}$. (a) and (d) are for $5 \mathrm{March}$, (b) and (e) for 13 March, and (c) and (f) for 21 March. Contours show modeled SSHA (difference between SSH and the time-averaged SSH for January-March). Solid and dashed contours represent positive and negative values, respectively. The contour interval is $0.05 \mathrm{~m}$.

Figure 16. Time series of (a) buoyancy frequency squared, $N^{2}$, and (b) rate of change of buoyancy frequency squared, $\partial N^{2} / \partial t$. Solid and dashed blue lines are for BGC floats 2903329 and 2903330, respectively. In (b), the blue lines were obtained by the linear fit to $N^{2}$ in (a). The solid red line is $\partial N^{2}{ }_{B U O} / \partial t ;$ the solid black line is $\partial N^{2}{ }_{G E O} / \partial t$ from float data.

Table 1. Case periods determined from the depth of the mixed layer.

Table 2. Rates of increase $(+)$ of POC and decrease $(-)$ of nitrate concentrations during each case and $\mathrm{POC} / \mathrm{Chl} a$ ratios during mixing and restratification periods.

Table 3. Rates of decrease (-) of POC and oxygen and increase $(+)$ of nitrate concentrations for each float after Case 4. 
https://doi.org/10.5194/bg-2022-9

Preprint. Discussion started: 13 January 2022

(C) Author(s) 2022. CC BY 4.0 License.
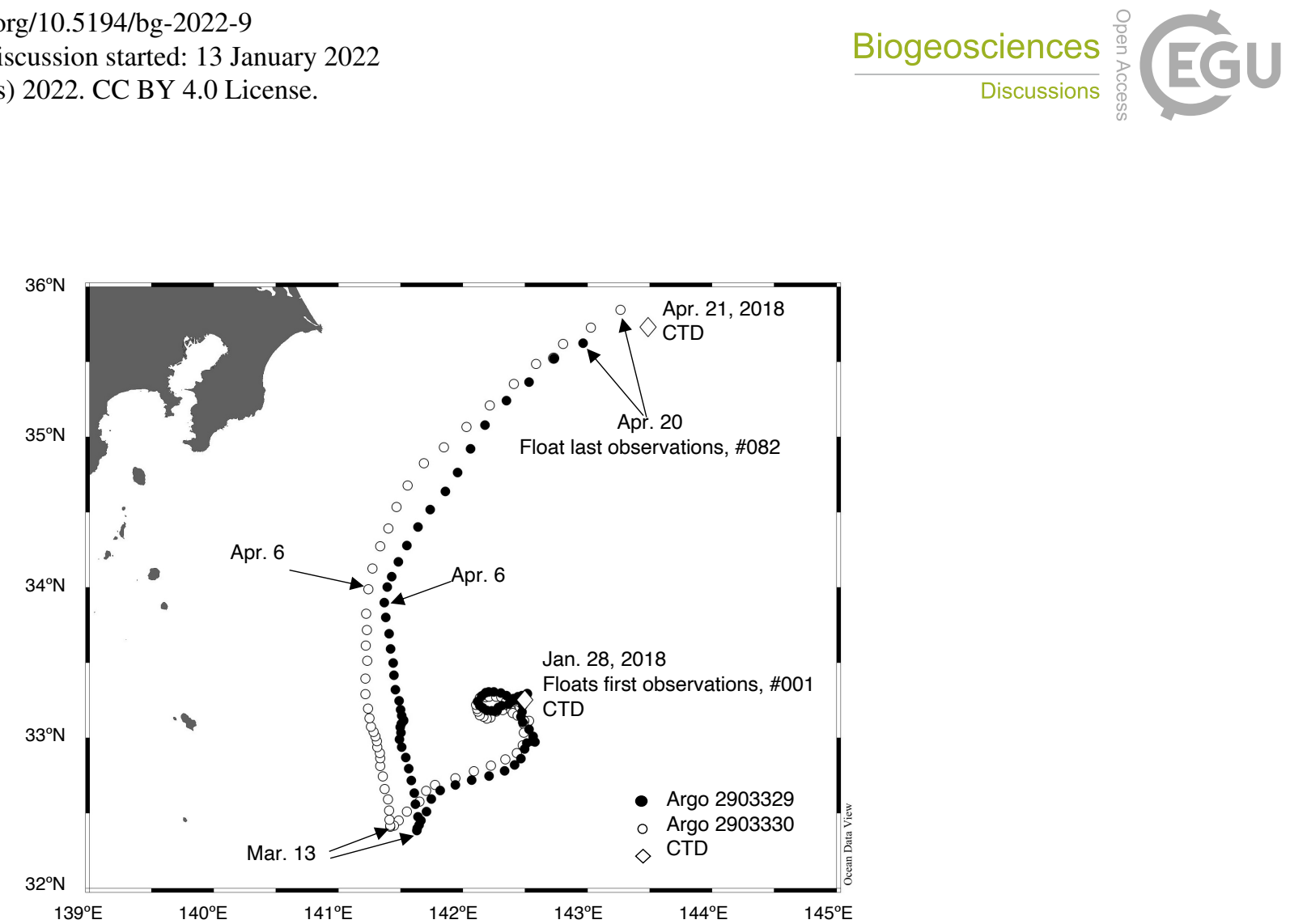

Figure 1: Map of the study area showing the two Argo float trajectories (black circles: Argo 2903329; open circles: Argo 290330)

and R/V Shinsei-maru CTD stations where water samples were collected (open diamonds). 
https://doi.org/10.5194/bg-2022-9

Preprint. Discussion started: 13 January 2022

(C) Author(s) 2022. CC BY 4.0 License.

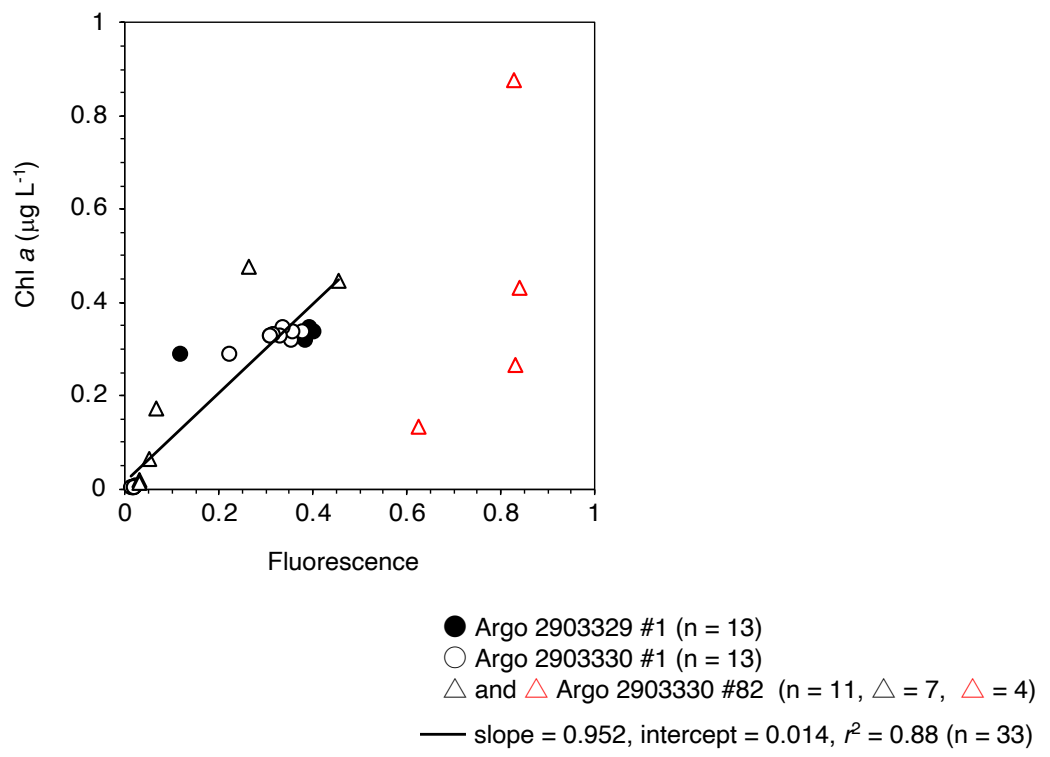

Figure 2: The relationship between fluorescence measured by floats and Chl $a$ concentrations from water samples. Black and open circles show measurements from the first profiles of Argo floats 2903329 and 2903330 vs Chl $a$ concentrations. Red open triangles show measurements from the final profile of Argo float 2903330 vs Chl $a$ concentrations. The black line shows the linear fit to data without the four outliers (red open triangles). 
https://doi.org/10.5194/bg-2022-9

Preprint. Discussion started: 13 January 2022

(c) Author(s) 2022. CC BY 4.0 License.
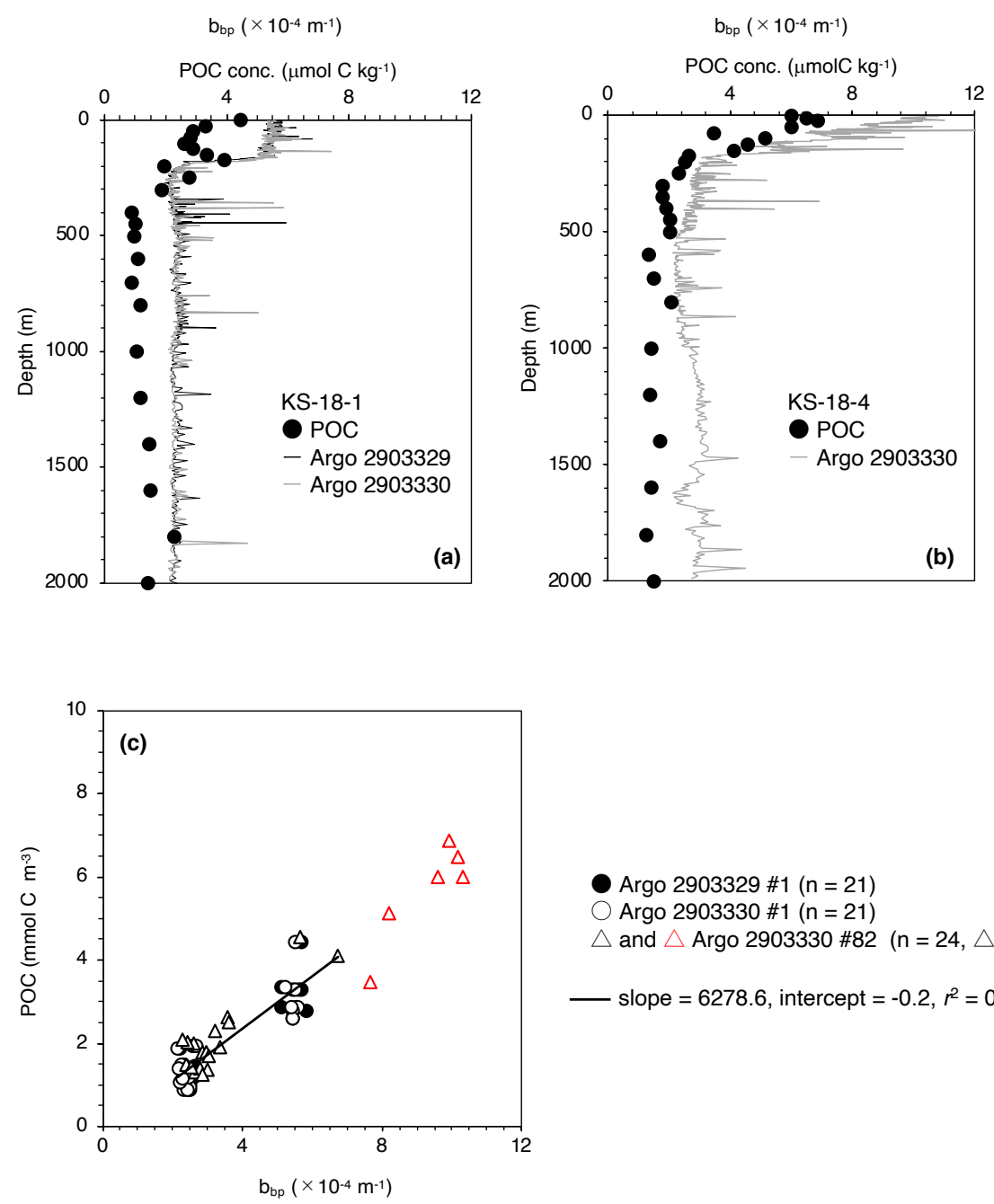

Argo $2903329 \# 1(n=21)$

Argo $2903330 \# 1(n=21)$

$\triangle$ and $\triangle$ Argo $2903330 \# 82(\mathrm{n}=24, \triangle=18, \triangle=6)$

- slope $=6278.6$, intercept $=-0.2, r^{2}=0.80(n=60)$

Figure 3: (a) Optical backscatter ( $\left.b_{b p}, 700 \mathrm{~nm}\right)$ from the first profile of Argo floats 2903329 and 2903330 and POC sampled on the same day at the float deployment site during the KS-18-1 cruise. Black circles show measured POC concentrations. Black and gray lines show $b_{b p}$ profiles of Argo float 2903329 and 2903330, respectively. (b) $b_{b p}$ from the final profile of Argo float 2903329 and POC sampled on the same day at the float recovery site during KS-18-4 cruise. (c) The relationship between $b_{b p}$ and POC. Black and open circles show measurements from the first profile of Argo float 2903329 and 2903330 vs POC concentrations. Black and red open triangles show measurements from the final profile of Argo float 2903329 vs POC concentrations. The black line shows the linear fit to data without the six outliers (red open triangles). 
https://doi.org/10.5194/bg-2022-9

Preprint. Discussion started: 13 January 2022

(c) Author(s) 2022. CC BY 4.0 License.
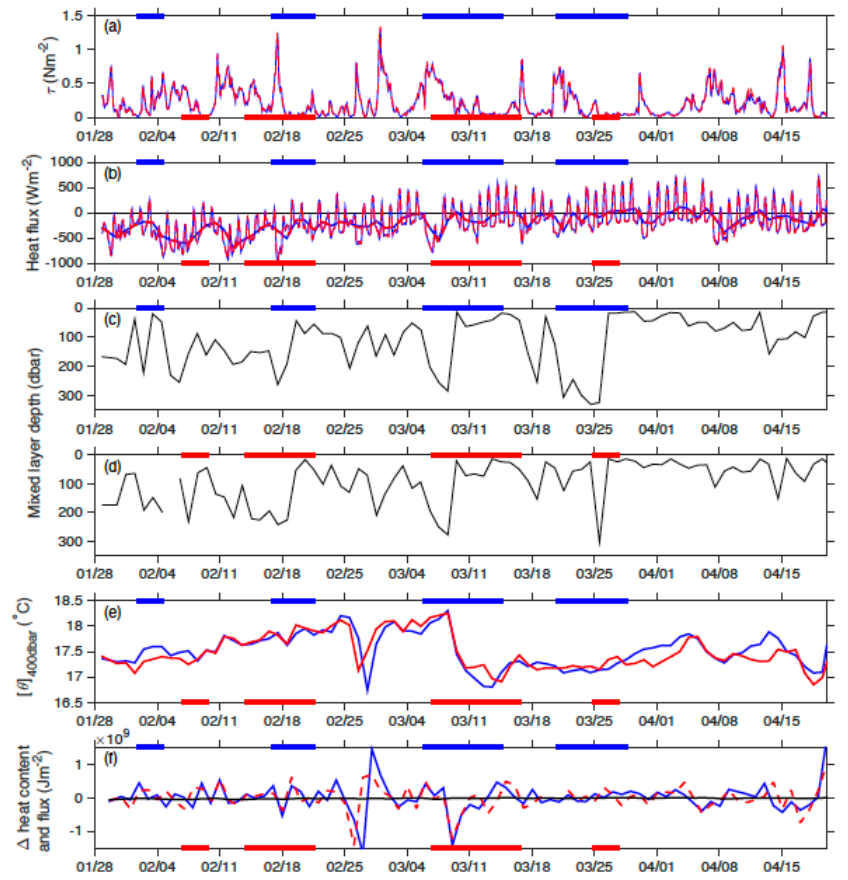

Figure 4: (a) Hourly wind stress and (b) heat flux at float positions. Hourly float positions were linearly interpolated between daily positions. Blue solid and red dashed lines indicate data for floats 2903329 and 2903330 , respectively. Thick red and blue lines in (b) show 24-h running averages. Negative values represent surface cooling. Mixed layer depth for floats (c) 2903329 and (d) 2903330.

(e) Average potential temperature ( $\theta$ ) above 400 dbar. Blue and red lines indicate floats 2903329 and 2903330 , respectively. (f)

Change of heat content (blue line for float 2903329 and red dashed line for float 2903330) and surface heat flux (black solid line).

Blue and red lines at the top or bottom of each plot mark the periods of the post-storm restratification events shown in Table 1. 
https://doi.org/10.5194/bg-2022-9

Preprint. Discussion started: 13 January 2022

(c) Author(s) 2022. CC BY 4.0 License.

(a) Temperature $\left({ }^{\circ} \mathrm{C}\right)$
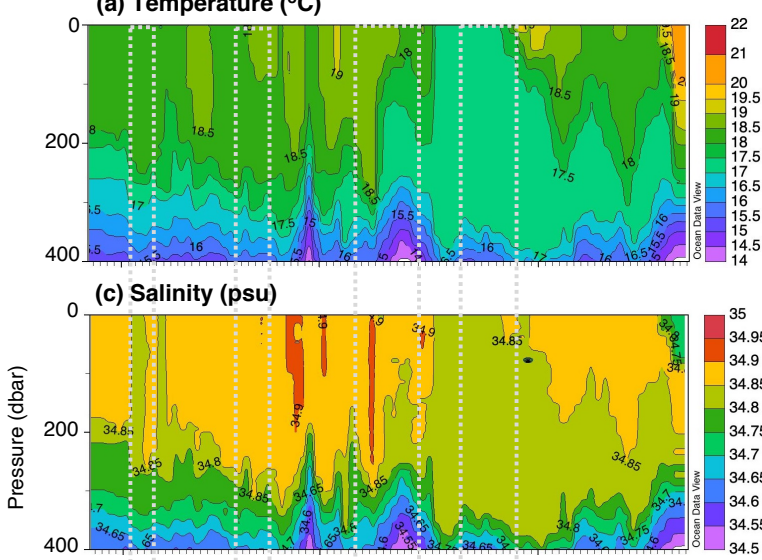

(e) Sigma-theta $\left(\mathrm{kg} \mathrm{m}^{-3}\right)$ (b) Temperature $\left({ }^{\circ} \mathrm{C}\right)$

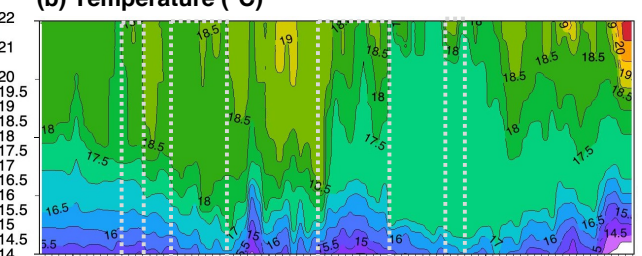

(d) Salinity (psu)

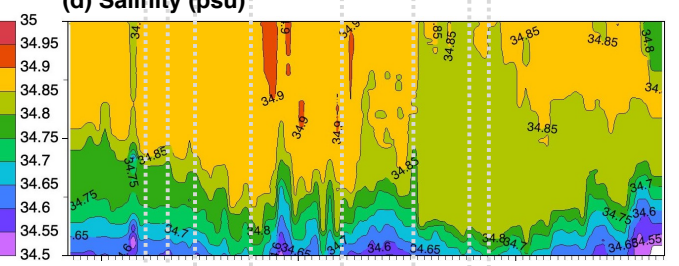

(f) Sigma-theta $\left(\mathrm{kg} \mathrm{m}^{-3}\right)$
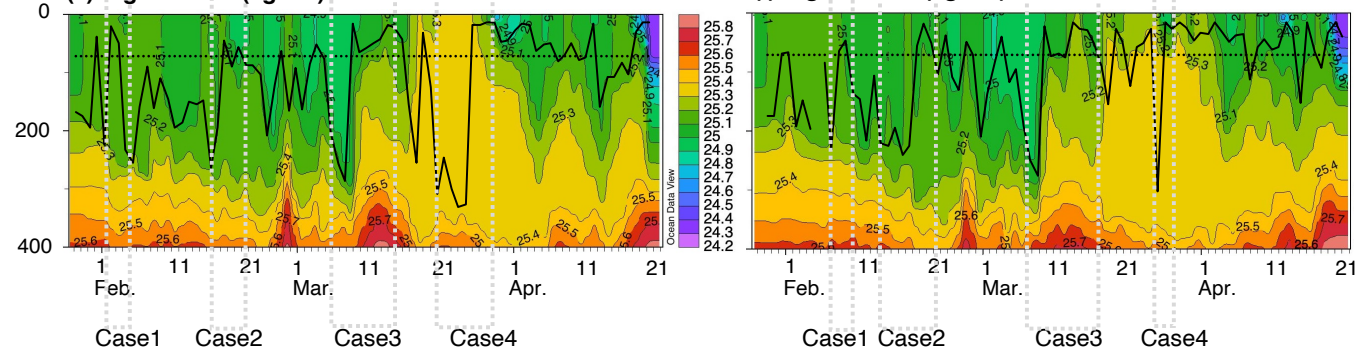

Figure 5: Time-series of vertical profiles of $(a, b)$ temperatures, $(c, d)$ salinities, and $(e, f)$ potential densities $\left(\sigma_{\theta}\right)$ observed by Argo

floats 2903329 and 2903330 . Bold lines in e and $f$ indicate the depth of the mixed layer. Broken lines in e and $f$ indicate the depth of the euphotic layer $(70 \mathrm{~m})$. 
Argo 2903329

(a) Oxygen concentration $\left(\mu \mathrm{mol} \mathrm{O}_{2} \mathrm{~kg}^{-1}\right)$

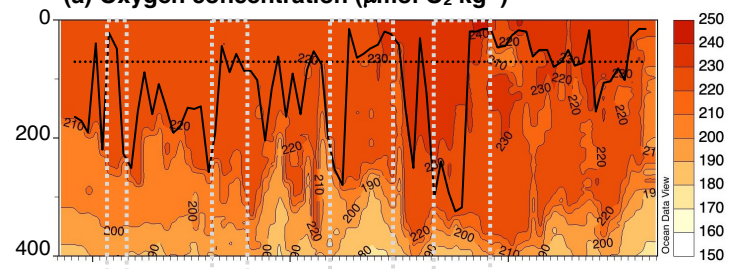

(c) Oxygen saturation ratio (\%)

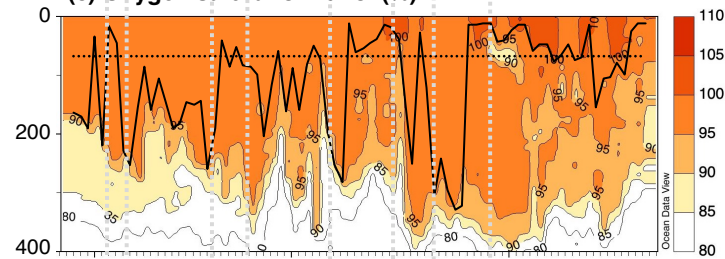

(e) Chl a $\left(\mathrm{mg} \mathrm{m}^{-3}\right)$

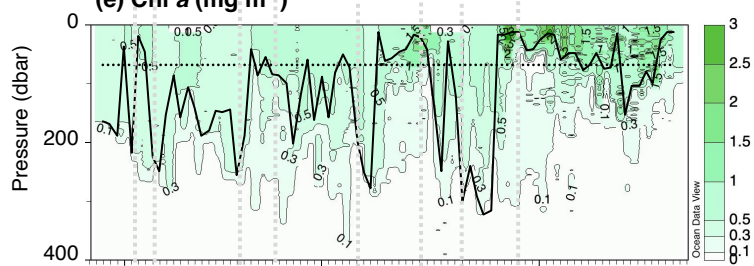

(g) Nitrate ( $\mu \mathrm{mol} \mathrm{N} \mathrm{kg-1)}$

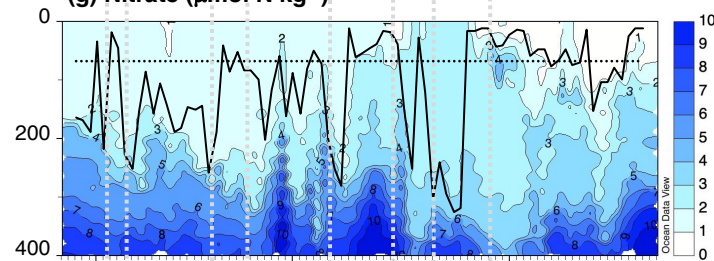

(i) Particulate organic carbon $\left(\mu \mathrm{mol} \mathrm{C} \mathrm{kg}^{-1}\right)$

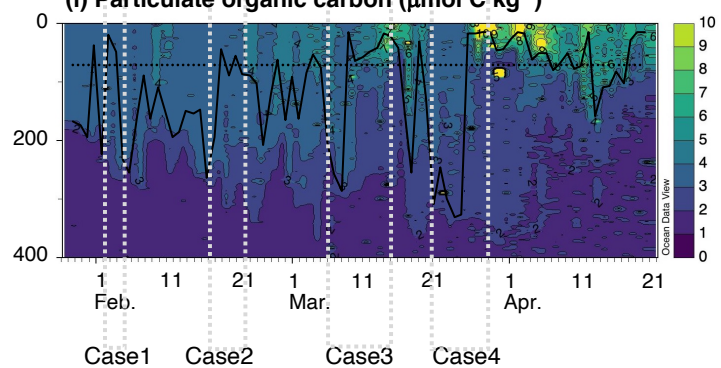

Argo 2903330

(b) Oxygen concentration $\left(\mu \mathrm{mol} \mathrm{O}_{2} \mathrm{~kg}^{-1}\right)$

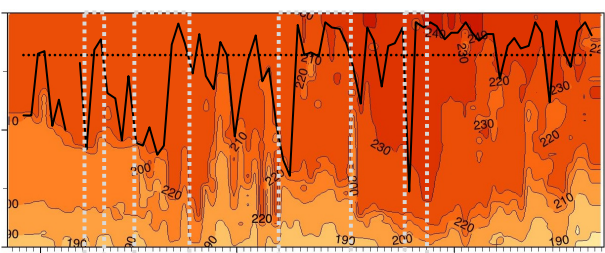

(d) Oxygen saturation ratio (\%)

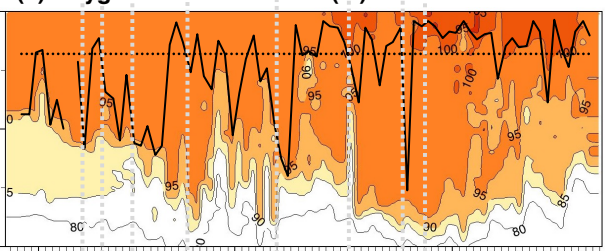

(f) $\mathrm{Chl} a\left(\mathrm{mg} \mathrm{m}^{-3}\right)$

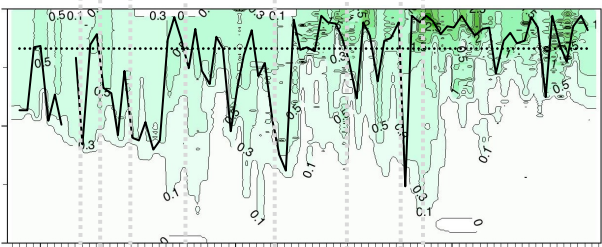

(h) Nitrate $\left(\mu \mathrm{mol} \mathrm{N} \mathrm{kg}{ }^{-1}\right)$

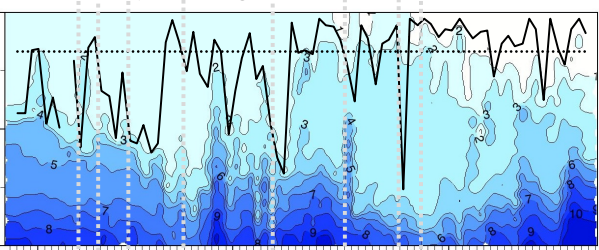

(j) Particulate organic carbon $\left(\mu \mathrm{mol} \mathrm{C} \mathrm{kg}{ }^{-1}\right)$

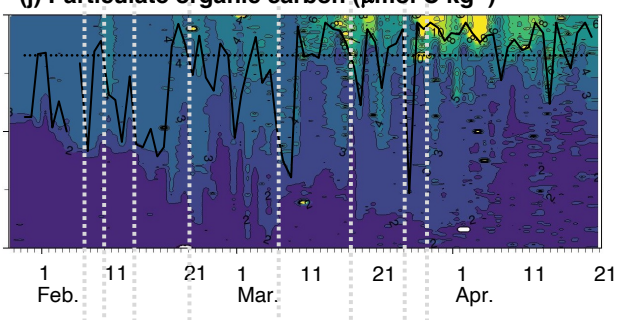

Case1 Case2 Case3 Case4

Figure 6: Time-series of vertical profiles of $(a, b)$ oxygen concentrations, $(c, d)$ oxygen saturation ratios, $(e, f)$ Chl $a$ concentrations,

(g, h) nitrate concentrations, (i, j) Particulate organic carbon (POC) concentrations observed by Argo floats 2903329 and 2903330.

Bold lines indicate the depth of the mixed layer. Broken lines indicate the depth of the euphotic layer $(70 \mathrm{~m})$. 
https://doi.org/10.5194/bg-2022-9

Preprint. Discussion started: 13 January 2022

(c) Author(s) 2022. CC BY 4.0 License.

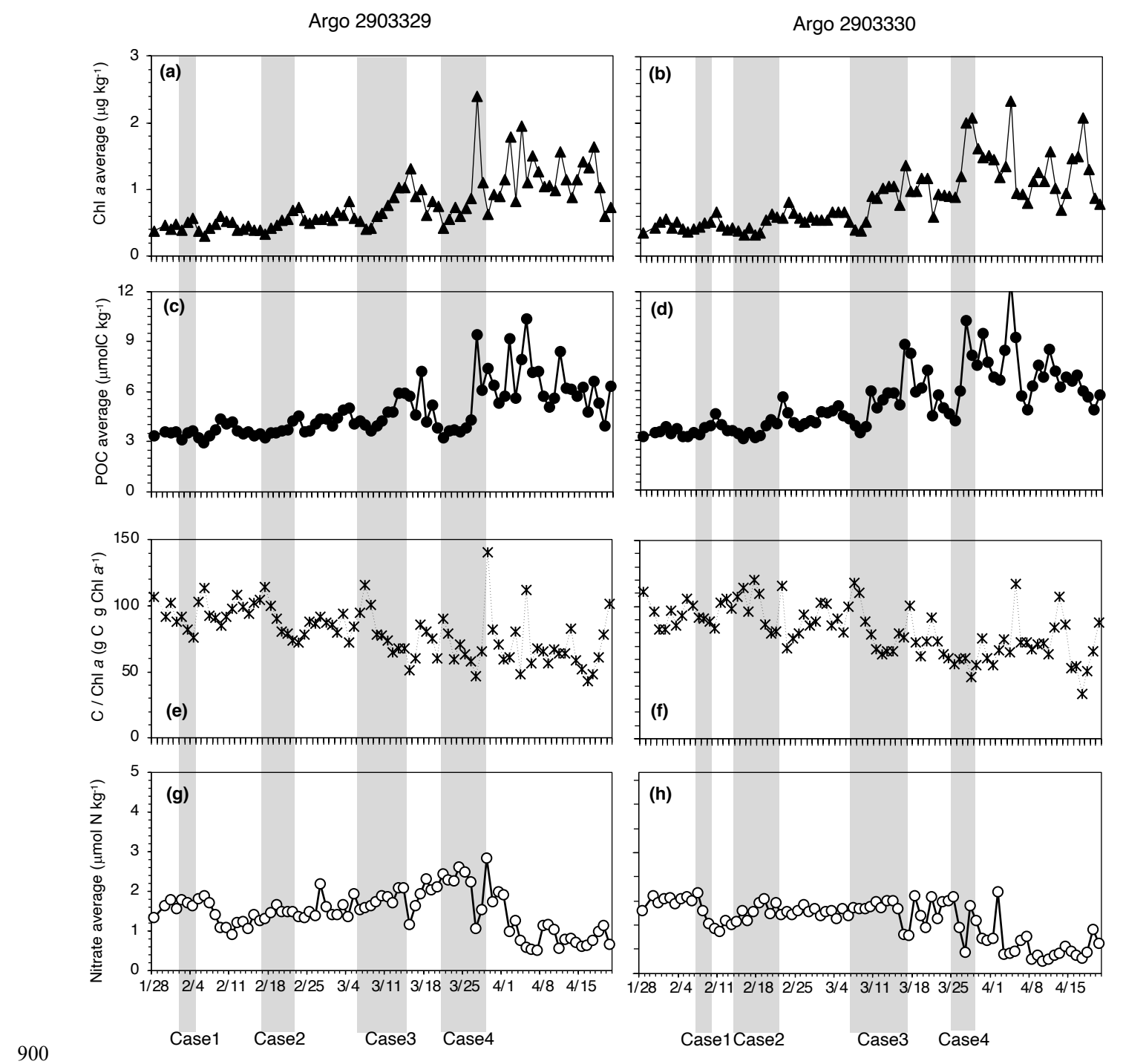

Figure 7: Time-series of the euphotic layer (0-70 m) averaged (a, b) Chl $a$, (c, d) POC, (e, f) C/Chl $a$ ratio, and (g, h) nitrate concentrations observed by floats 2903329 and 2903330 . 
https://doi.org/10.5194/bg-2022-9

Preprint. Discussion started: 13 January 2022

(c) Author(s) 2022. CC BY 4.0 License.
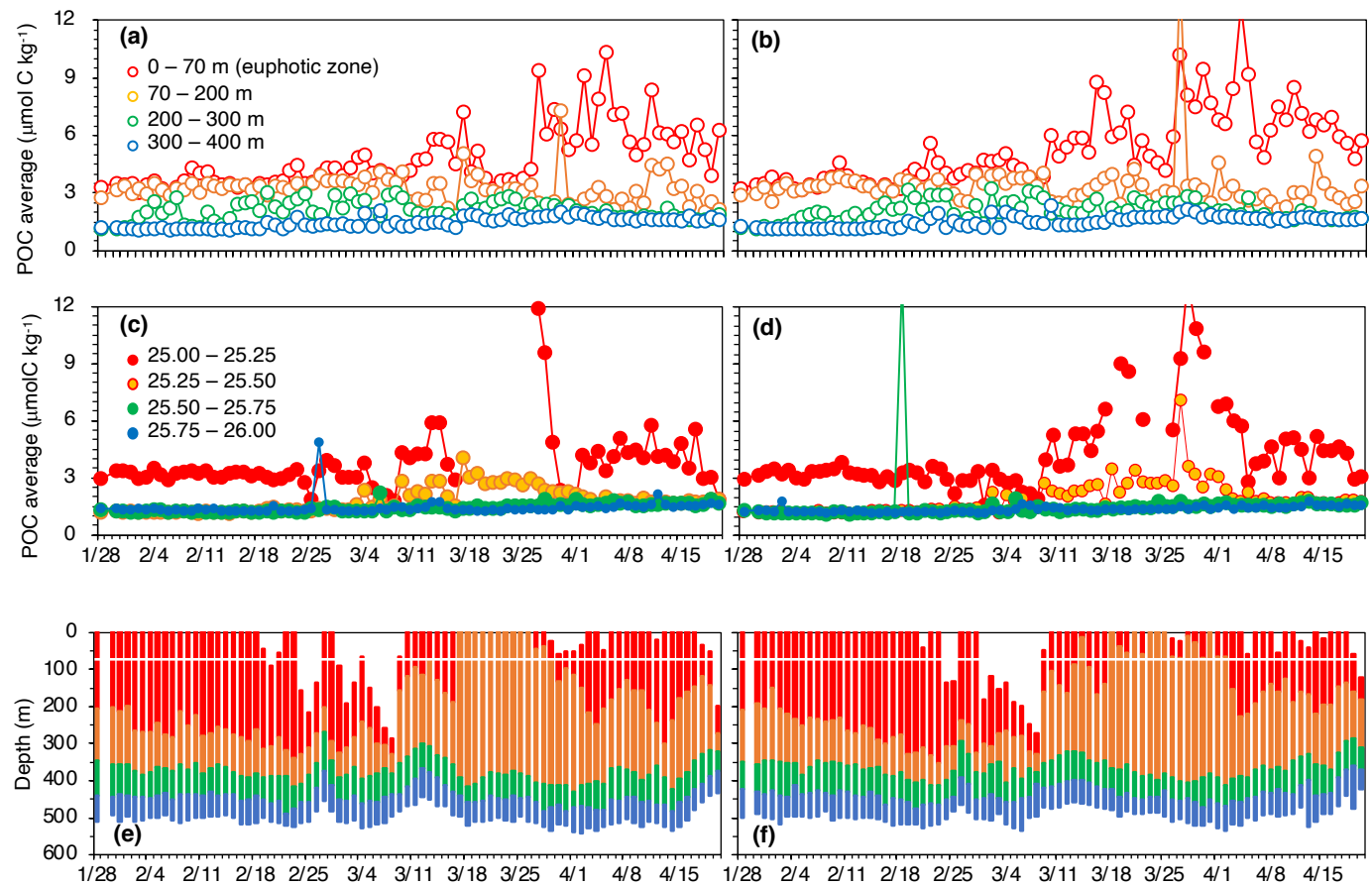

Figure 8: Time-series of $(a, b)$ average POC concentration in each depth range and $(c, d)$ average POC concentration in each density range observed by floats 2903329 and 2903330 . (e, g) Time-series showing the depths and thicknesses of each density range. Red, orange, green, and blue symbols indicate the $\sigma_{\theta}$ ranges of $25.00-25.25,25.25-25.50,25.50-25.75$, and $25.75-26.00$, respectively. White lines in $\mathrm{e}$ and $\mathrm{f}$ indicate the depth of the euphotic layer $(70 \mathrm{~m})$. 
https://doi.org/10.5194/bg-2022-9

Preprint. Discussion started: 13 January 2022

(C) Author(s) 2022. CC BY 4.0 License.

(c) (i)
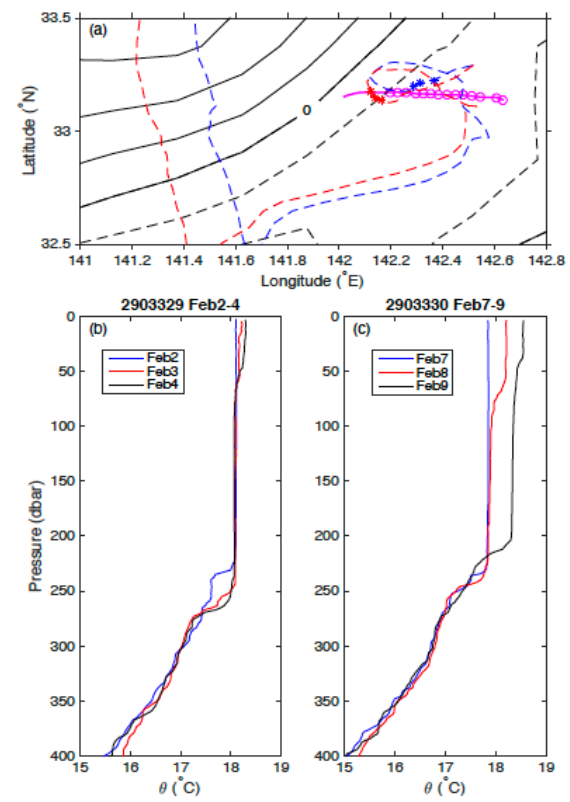

Figure 9: (a) SSHA contours on 7 February and BGC float trajectories (blue and red dashed lines indicate floats 2903329 and 2903330, respectively). Solid and dashed lines are positive and negative SSHA, respectively, and the contour interval is $0.05 \mathrm{~m}$. Blue and red asterisks are daily float positions for the period of Case 1. The magenta line shows the trajectory of the SeaGlider between

7 and 10 February, and the magenta circles are observation positions between 7 and 9 February. (b) Vertical profiles from 2 to 4 February of potential temperature from float 2903329 and (c) from 7 to 9 February from float 2903330. 
https://doi.org/10.5194/bg-2022-9

Preprint. Discussion started: 13 January 2022

(C) Author(s) 2022. CC BY 4.0 License.

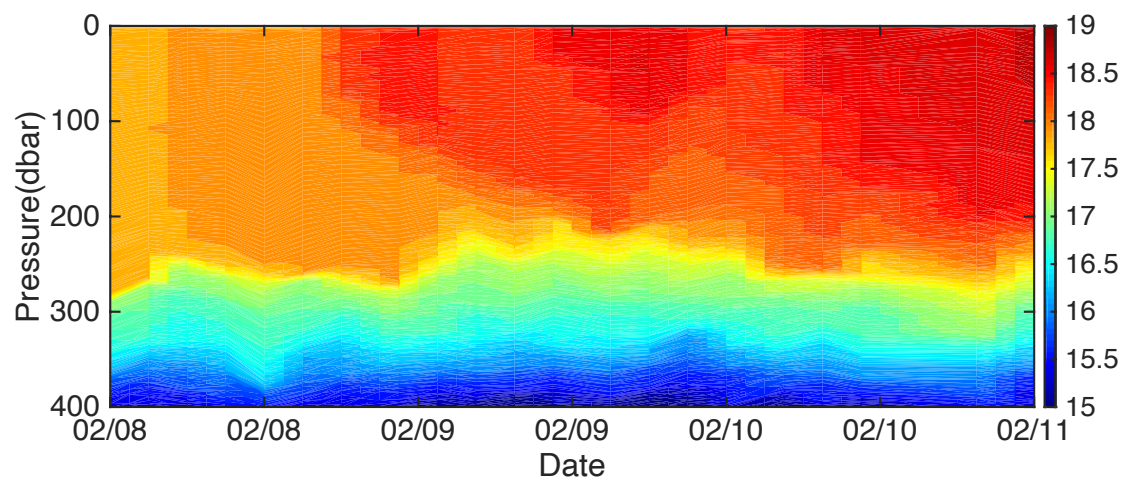

Figure 10: Time series of vertical profiles of potential temperature from SeaGlider data. A fixed time (the start of profiling) was used to generate the figure. 
https://doi.org/10.5194/bg-2022-9

Preprint. Discussion started: 13 January 2022

(C) Author(s) 2022. CC BY 4.0 License.

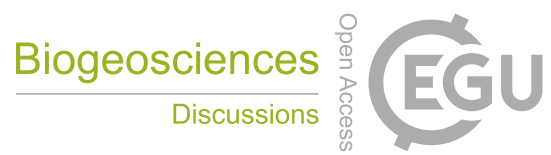

(c) (1)
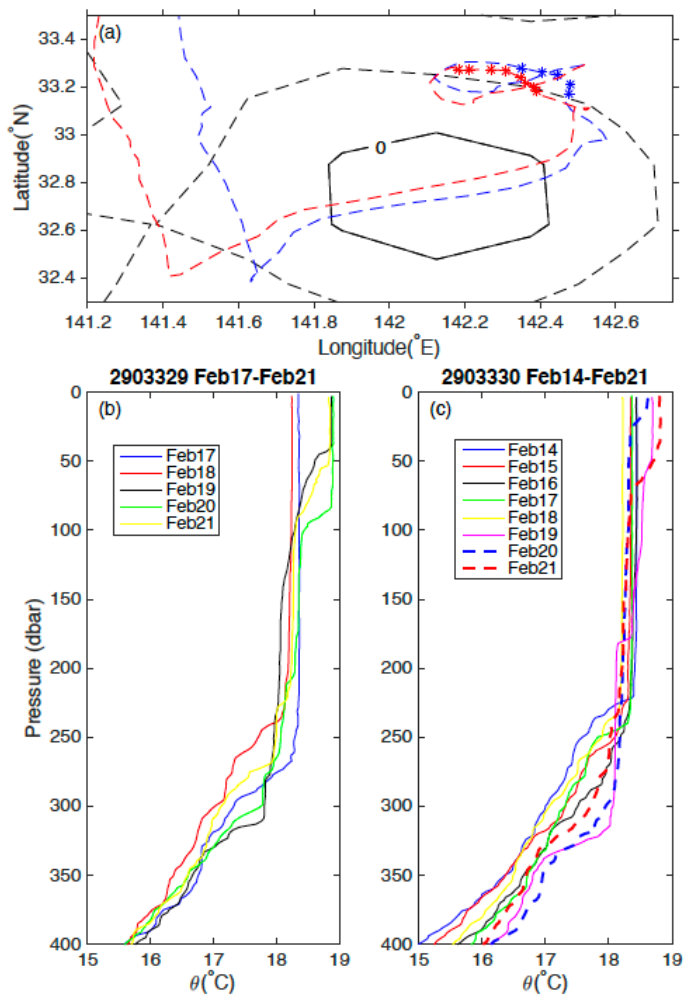

Figure 11: Same as Figure 9, but for Case 2. SSHA contours in (a) are for 20 February. Asterisks in (a) are BGC float profiling positions during Case 2. Vertical profiles of potential temperature in (c) are for 17-21 February and (d) 14-21 February. 
https://doi.org/10.5194/bg-2022-9

Preprint. Discussion started: 13 January 2022

(C) Author(s) 2022. CC BY 4.0 License.
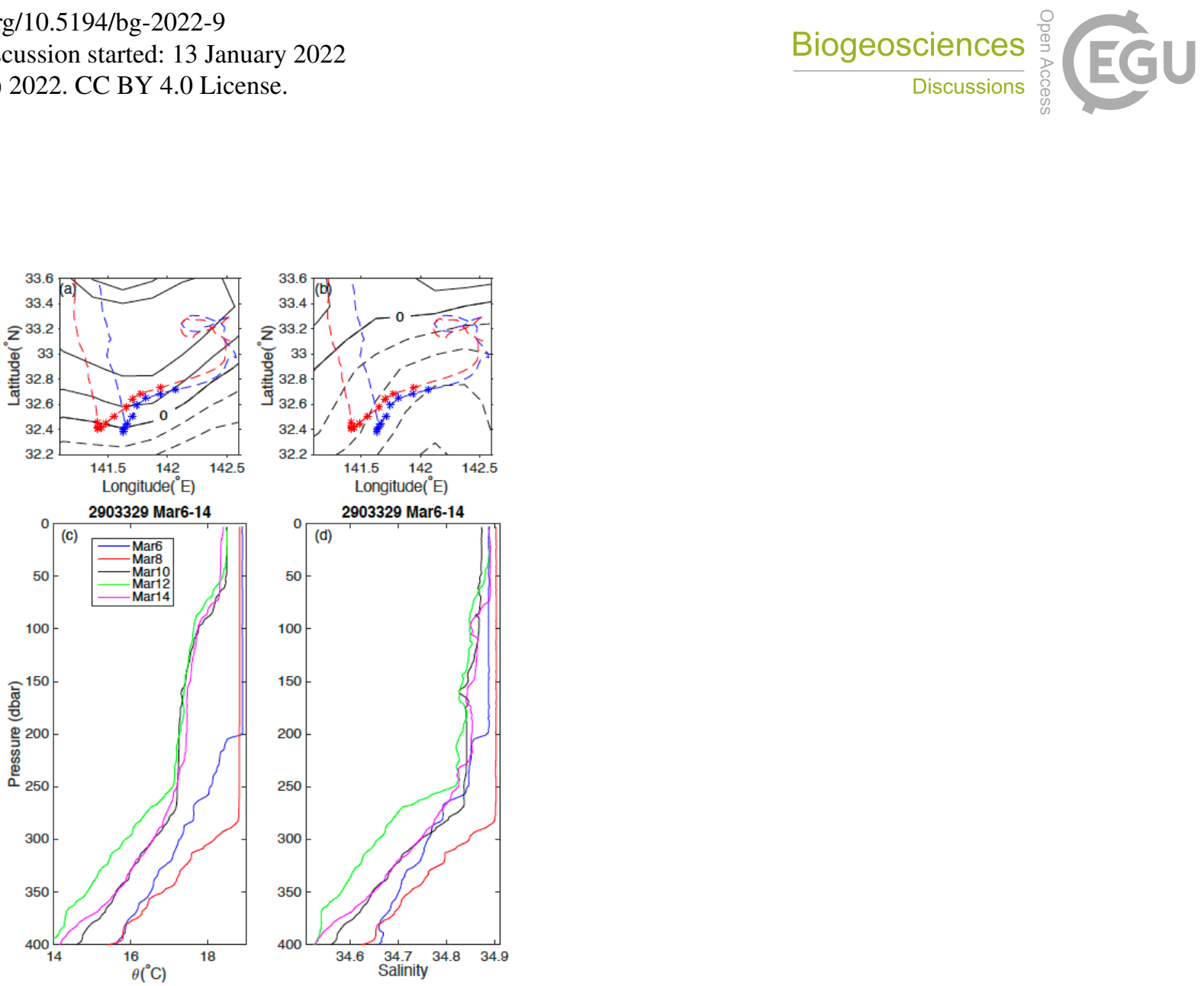

Figure 12: Same as Figure 9, but for Case 3. (a) and (b) SSHA contours for 8 and 13 March, respectively. (c) and (d) Vertical profiles on alternate days from 6 to 14 March of potential temperature and salinity, respectively, from BGC float no. 2903329. 
https://doi.org/10.5194/bg-2022-9

Preprint. Discussion started: 13 January 2022

(C) Author(s) 2022. CC BY 4.0 License.
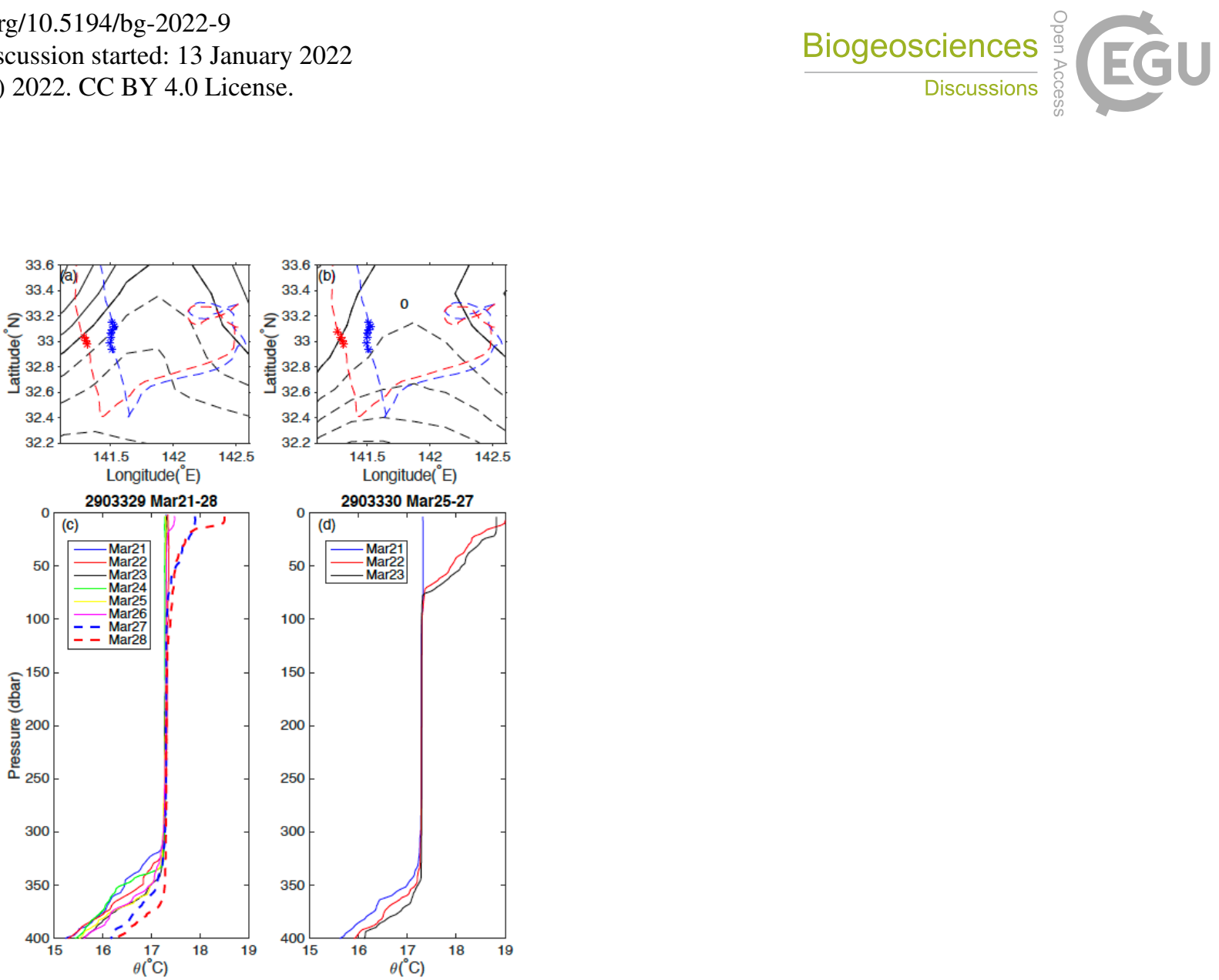

Figure 13: Same as Figure 9, but for Case 4. (a) and (b) SSHA contours for 22 and 27 March, respectively. (c) Vertical profiles from 21 to 28 March of potential temperature from BGC float 2903329 and (d) from 21 to 23 March of potential temperature from BGC float 290330. 
https://doi.org/10.5194/bg-2022-9

Preprint. Discussion started: 13 January 2022

(c) Author(s) 2022. CC BY 4.0 License.
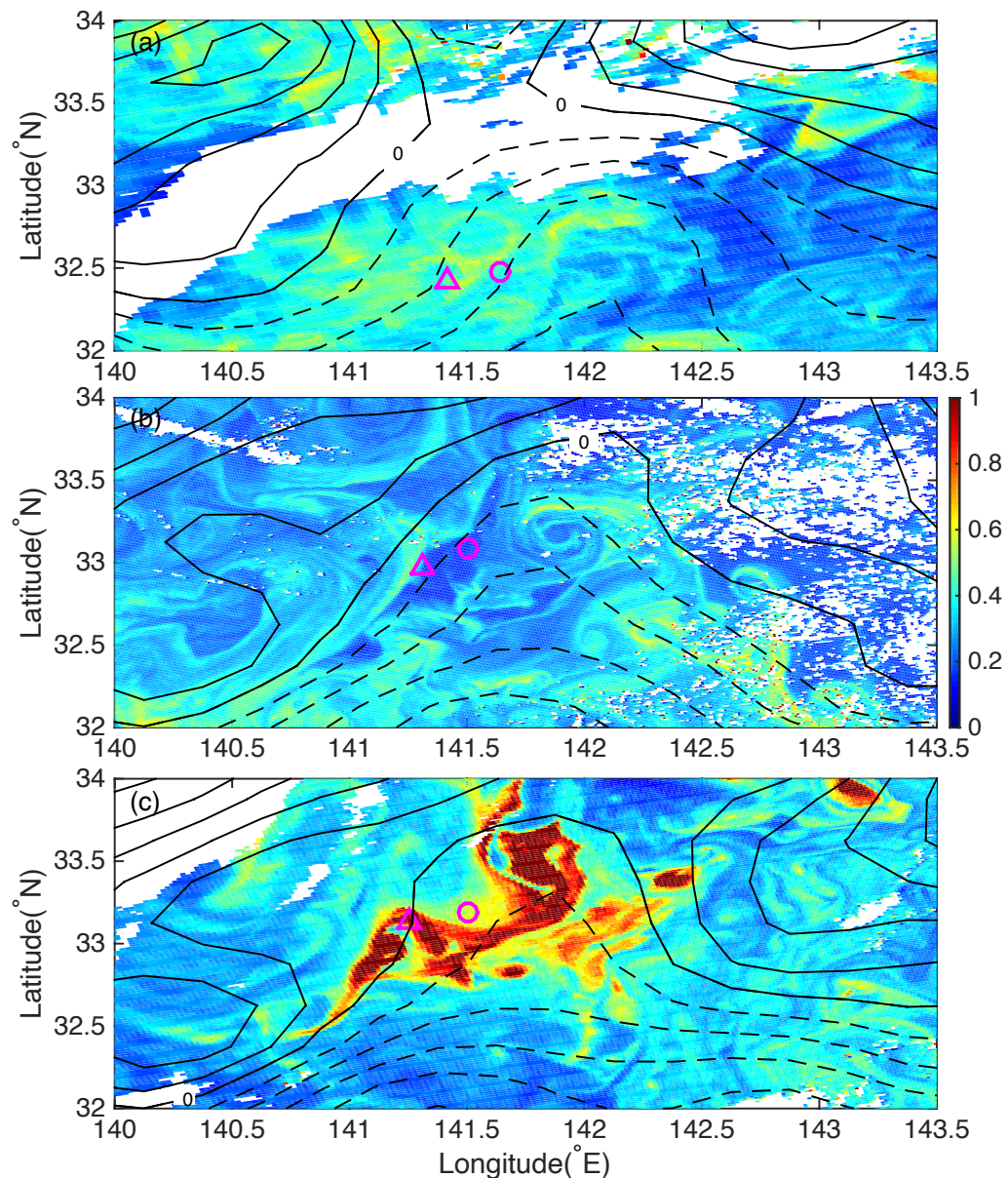

Figure 14: SSHA contours and sea surface chlorophyll $a$ concentrations ( $\mathrm{mg} \mathrm{m}^{-3}$, color scale) derived from satellite data on (a) 15

March, (b) 25 March, and (c) 29 March. Solid and dashed lines are positive and negative, respectively. Contour interval is $0.05 \mathrm{~m}$.

The magenta circles and triangles show the positions of BGC floats 2903329 and 2903330, respectively. Storms (see Table 1 and Fig.

2) passed through this area on 7 March (before Case 3) and 21 March (before Case 4). 
https://doi.org/10.5194/bg-2022-9

Preprint. Discussion started: 13 January 2022

(c) Author(s) 2022. CC BY 4.0 License.
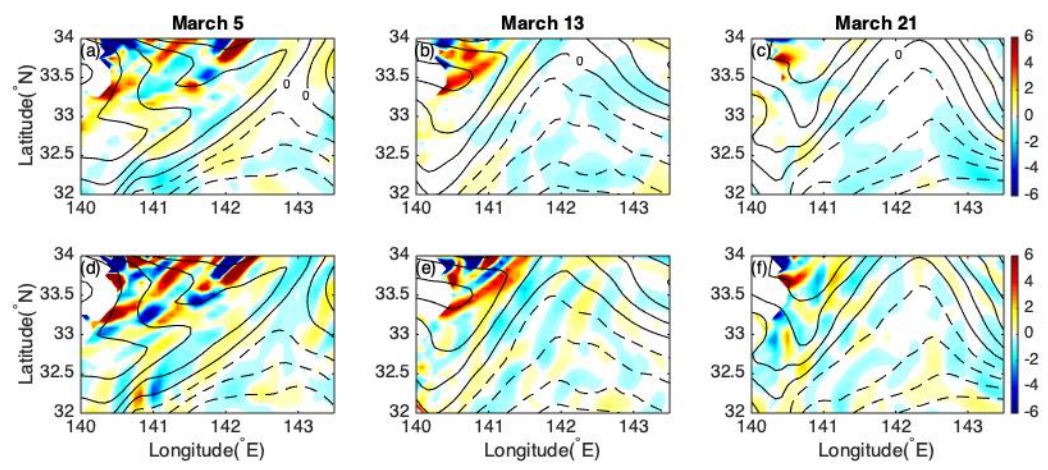

Figure 15: Horizontal distributions of (a-c) the normalized $Q$ vector, $10^{13} \times Q \cdot \frac{\nabla_{b} b}{\left|\nabla_{b} b\right|}$, and (d-f) the horizontal divergence of the $Q$ vector, $10^{17} \times-\nabla_{h} \cdot Q$, at $380 \mathrm{~m}$. (a) and (d) are for 5 March, (b) and (e) for 13 March, and (c) and (f) for 21 March. Contours show modeled SSHA (difference between SSH and the time-averaged SSH for January-March). Solid and dashed contours represent positive and negative values, respectively. The contour interval is $0.05 \mathrm{~m}$. 
https://doi.org/10.5194/bg-2022-9

Preprint. Discussion started: 13 January 2022

(C) Author(s) 2022. CC BY 4.0 License.
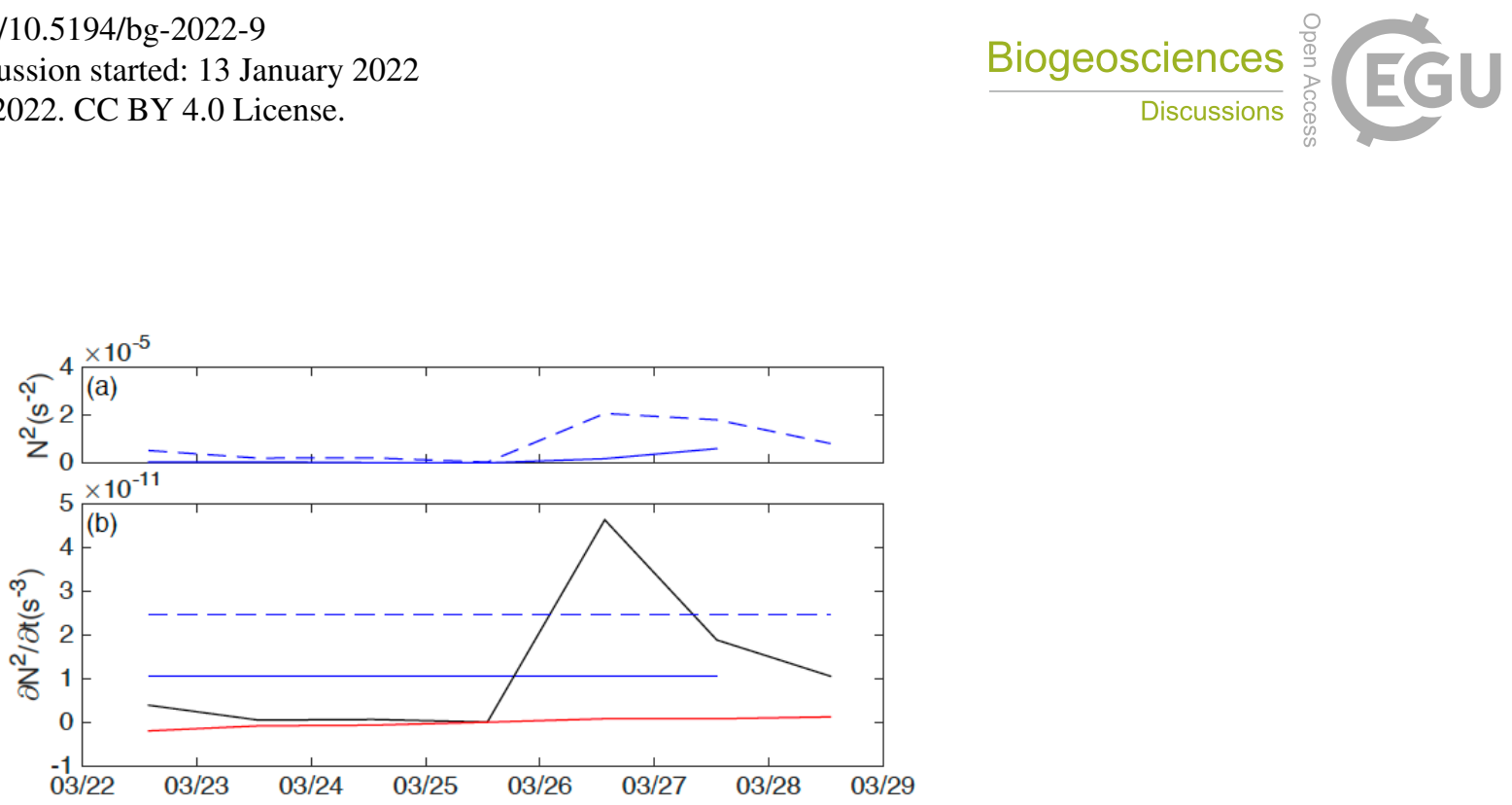

Figure 16: Time series of (a) buoyancy frequency squared, $N^{2}$, and (b) rate of change of buoyancy frequency squared, $\partial N^{2} / \partial t$. Solid and dashed blue lines are for BGC floats 2903329 and 2903330 , respectively. In (b), the blue lines were obtained by the linear fit to

$N^{2}$ in (a). The solid red line is $\partial N^{2}{ }_{B U} / \partial t$; the solid black line is $\partial N^{2}{ }_{G E O} / \partial t$ from float data. 
https://doi.org/10.5194/bg-2022-9

Preprint. Discussion started: 13 January 2022

(C) Author(s) 2022. CC BY 4.0 License.

Table 1: Case periods determined from the depth of the mixed layer.

\begin{tabular}{|c|c|c|c|}
\hline Case \# & $\begin{array}{l}\text { Period } \\
\text { (days) }\end{array}$ & $\begin{array}{l}\text { Mixing period } \\
\text { (days) }\end{array}$ & $\begin{array}{l}\text { Stratified period } \\
\text { (days) }\end{array}$ \\
\hline \multicolumn{4}{|c|}{ Float 2903329} \\
\hline$\# 1$ & $\begin{array}{l}2-4 \text { Feb. } \\
\text { (3 days) }\end{array}$ & $\begin{array}{l}2 \text { Feb. } \\
\text { (1 day) }\end{array}$ & $\begin{array}{l}3-4 \text { Feb. } \\
(2 \text { days })\end{array}$ \\
\hline \#2 & $\begin{array}{l}17-21 \text { Feb. } \\
(5 \text { days })\end{array}$ & $\begin{array}{l}17-18 \text { Feb. } \\
(2 \text { days })\end{array}$ & $\begin{array}{l}19-21 \text { Feb. } \\
(3 \text { days })\end{array}$ \\
\hline \#3 & $\begin{array}{l}6-14 \text { Mar.* } \\
(9 \text { days })\end{array}$ & $\begin{array}{l}6-8 \text { Mar. } \\
\text { (3 day) }\end{array}$ & $\begin{array}{l}9-14 \text { Mar. } \\
\text { ( } 6 \text { days })\end{array}$ \\
\hline \#4 & $\begin{array}{l}21-28 \text { Mar.* } \\
(8 \text { days })\end{array}$ & $\begin{array}{l}21-25 \text { Mar. } \\
(5 \text { days })\end{array}$ & $\begin{array}{l}26-28 \text { Mar. } \\
(3 \text { days })\end{array}$ \\
\hline \multicolumn{4}{|c|}{ Float 2903330} \\
\hline$\# 1$ & $\begin{array}{l}7-9 \text { Feb. } \\
\text { (3 days) }\end{array}$ & $\begin{array}{l}7 \text { Feb. } \\
\text { (1 day) }\end{array}$ & $\begin{array}{l}8-9 \text { Feb. } \\
(2 \text { days })\end{array}$ \\
\hline \#2 & $\begin{array}{l}14-21 \mathrm{Feb} . \\
(8 \text { days })\end{array}$ & $\begin{array}{l}14-18 \text { Feb. } \\
(5 \text { days })\end{array}$ & $\begin{array}{l}19-21 \text { Feb. } \\
(3 \text { days })\end{array}$ \\
\hline \#3 & $\begin{array}{l}7 \text { - } 16 \text { Mar. } \\
\text { (11 days) }\end{array}$ & $\begin{array}{l}7-8 \text { Mar. } \\
\text { (2 day) }\end{array}$ & $\begin{array}{l}9-16 \text { Mar. } \\
(8 \text { days })\end{array}$ \\
\hline$\# 4$ & $\begin{array}{l}25-27 \text { Mar.* } \\
\text { ( } 3 \text { days) }\end{array}$ & $\begin{array}{l}25 \text { Mar. } \\
\text { (1 day) }\end{array}$ & $\begin{array}{l}26-27 \text { Mar. } \\
(2 \text { days })\end{array}$ \\
\hline
\end{tabular}

* The end of the event was determined from the density profile. 
https://doi.org/10.5194/bg-2022-9

Preprint. Discussion started: 13 January 2022

(C) Author(s) 2022. CC BY 4.0 License.

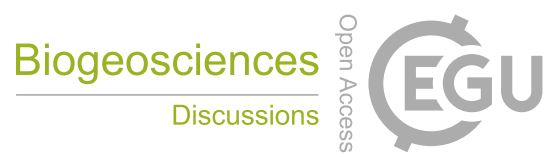

955 Table 2: Rates of increase $(+)$ of POC and decrease (-) of nitrate concentrations during each case and POC/Chl $a$ ratios during mixing and restratification periods.

\begin{tabular}{|c|c|c|c|c|}
\hline Case \# & $\begin{array}{l}\text { POC } \\
\left(\mu \mathrm{molC} \mathrm{kg} \mathrm{kg}^{-1}\right)\end{array}$ & $\begin{array}{l}\text { Nitrate } \\
\left(\mu \mathrm{molN} \mathrm{kg}{ }^{-1} \mathrm{~d}^{-1}\right)\end{array}$ & $\begin{array}{l}\mathrm{C} / \mathrm{Chl} a(\mathrm{~g} \mathrm{C} \\
\left.\mathrm{g} \mathrm{Chl} a^{-1}\right) \text { in } \\
\text { mixing period }\end{array}$ & $\begin{array}{l}\mathrm{C} / \mathrm{Chl} a(\mathrm{~g} \mathrm{C} \\
\left.\mathrm{g} \mathrm{Chl} a^{-1}\right) \text { in } \\
\text { stratified period }\end{array}$ \\
\hline \multicolumn{5}{|l|}{ Float 2903329} \\
\hline$\# 1$ (2 - 4 Feb.) & +0.28 & -0.08 & 92 & 79 \\
\hline$\# 2$ (18 - 21 Feb. $)$ & +0.06 & -0.01 & 107 & 84 \\
\hline \#3 (8 - 14 Mar.) & +0.40 & +0.07 & 104 & 72 \\
\hline \#4 (25 - 28 Mar.) & +1.19 & -0.40 & 73 & 59 \\
\hline \multicolumn{5}{|l|}{ Float 2903330} \\
\hline$\# 1$ (7 - 9 Feb.) & +0.26 & -0.38 & 92 & 90 \\
\hline$\# 2$ (14 - 21 Feb.) & +0.24 & -0.04 & 110 & 83 \\
\hline \#3 (7 - 16 Mar.) & +0.43 & -0.04 & 115 & 74 \\
\hline \#4 (25 - 27 Mar.) & +3.02 & -0.69 & 57 & 59 \\
\hline
\end{tabular}


https://doi.org/10.5194/bg-2022-9

Preprint. Discussion started: 13 January 2022

(C) Author(s) 2022. CC BY 4.0 License.

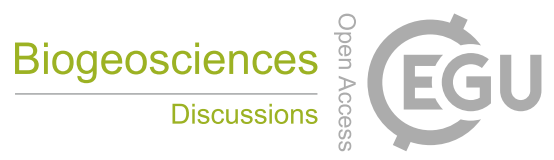

Table 3: Rates of decrease (-) of POC and oxygen and increase $(+)$ of nitrate concentrations for each float after Case 4.

\begin{tabular}{|c|c|c|c|}
\hline Float & $\begin{array}{l}\text { POC } \\
\left(\mu \mathrm{molC} \mathrm{kg} \mathrm{kg}^{-1}\right)\end{array}$ & $\begin{array}{l}\text { Oxygen } \\
\left(\mu \mathrm{molO}_{2} \mathrm{~kg}^{-1} \mathrm{~d}^{-1}\right)\end{array}$ & $\begin{array}{l}\text { Nitrate } \\
\left(\mu \text { molN kg-1 } \mathrm{d}^{-1}\right)\end{array}$ \\
\hline \multicolumn{4}{|l|}{$200-300 \mathrm{~m}$} \\
\hline $\begin{array}{l}2903329 \\
(29 \text { Mar. - } 2 \text { Apr.) }\end{array}$ & -0.09 & +0.02 & -0.03 \\
\hline $\begin{array}{l}2903330 \\
\text { (31 Mar. - } 3 \text { Apr.) }\end{array}$ & -0.05 & -0.62 & -0.04 \\
\hline
\end{tabular}

